\title{
Devotio christi en la Edad Moderna: la cofradía-mutualidad de la Esclavitud del Santo Cristo del Calvario de Mondéjar
}

\author{
José Miguel López VilLalba
}

UNED

\section{RESUMEN:}

Las cofradías permitieron, dentro de un espiritu corporativo, la participación de los diferentes sectores de la población. En ellas se englobó todo un mundo de solidaridad que transmitió a las capas más desfavorecidas una amplia labor asistencial, pero muchas de estas estructuras sociales se crearon para el benefi-

cio de sus miembros en caso de grave necesidad material: pobreza, enfermedad o muerte, apareciendo de este modo como las precursoras de las mutualidades modernas. Se ha estudiado en este trabajo la Esclavitud del Santo Cristo de Mondéjar que aparece como un ejemplo perfecto de corporación devocional devenida en la expresión más clara de la solidaridad de grupo, pues desarrolla como primera norma la caridad endógena. Por este motivo, se ha realizado, después de la introducción y de la metodología de análisis de la fuente, un completo estudio de dicha cofradia: orígenes, fines, hacienda, beneficios y obligaciones y finalmente los cargos. Por último, se presenta la transcripción completa de la documentación aportada.

\section{ABSTRACT}

The brotherhoods allowed the participation of different sections of population within a corporative spirit. All a world of solidarity was included, which supplied public assistence to the poors. Many of these social structures were created for the benefit of its members in case of an extreme need such as: poverty, illness or death, being the precursor of the modern friendly societies. This work studies the Esclavitud del Santo Cristo de Mondéjar, which can be taken as a perfect example of devotional corporation, becoming the clearest expression of the group solidarity, since its first rule is the internal charity. For that reason, after the introduction and the methodology of the sources analysis, a complete study of the brotherhood has been carried out: its origin, aims, properties, benefits, duties and posts. Finally a complete transcription of the documents studied is presented. 


\section{INTRODUCCIÓN}

El cristianismo desde su nacimiento se configuró como un fenómeno asociativo que fue creando colectividades para la práctica de las distintas actividades piadosas. El sentido que se dio a estos conjuntos les llevó a que se transformarán en una necesidad que ha evolucionado hasta nuestros días.

La extensión geográfica del cristianismo por toda Europa hizo que dicho fenómeno asociativo tuviese un carácter generalizado. Tras un periodo de incubación en la Alta Edad Media, donde nacieron tímidamente, será durante los últimos siglos del medievo, cuando se asista al desarrollo de tales asociaciones. En los primeros momentos tomaron las voces latinas: collegium, consorcium, etc, para designarse más tarde con apelativos que señalaban claramente sus fines y características: caritas, fraternitas, humanitas, etc, y finalmente, acabar generalizándose los nombres de cofradías y hermandades.

El desarrollo de la fundación de cofradías medievales se instala dentro del resurgimiento económico, demográfico y cultural que se produce en el continente europeo a partir del siglo XI y que conlleva la evolución de la artesanía y del comercio como parte del crecimiento económico de las ciudades. El aumento en la fabricación de manufacturas discurría paralelo a la expansión del comercio. El proceso productivo requería una gran cantidad de operarios diseminados en diferentes talleres que se complementaban en su etapa final con los ocupados en la faceta comercial. Este nivel de ocupación conllevó la expansión de los gremios, modelo de acción social y profesional para defensa de los colectivos laborales, que de este modo fueron consolidando sus posiciones estratégicas dentro de la estructura del poder urbano. Era un sistema de defensa mutualista que repetía las características estructurales de la sociedad feudal.

Asimismo las cofradías cristianas, que se presentaron desde el primer momento como expresión de unidad confraternal, se diversificaron en su estructura y fines, llegando a veces, tal como ha estudiado Roberti ${ }^{1}$, a confundirse con los gremios por los diferentes puntos que unen ambos tipos de asociaciones, debiendo recurrir en múltiples ocasiones al estudio adecuado de los estatutos fundacionales para determinar el grupo a que pertenecen. De este modo cuando los gremios fueron perseguidos, muchos colectivos se refugiaron bajo el aspecto de cofradías ya que su fin más destacado era el auxilio mutuo y la protección entre sus miembros. Desde este encubrimiento pudieron seguir vinculados a la práctica de poder dentro de la sociedad urbana por medio de la influencia en los cargos conceji-

1. Roberti, M., Le corporazione padovane d'arte e mestieri. Padova, 1902. 
les o en los grupos económicos. Estas cofradías defendían sus intereses artesanales y comerciales, aunque siempre mantenían un apartado benéfico y asistencial ${ }^{2}$.

Delaruelle en su obra sobre la piedad popular en la Edad Media, en un intento de clarificación de tan complejo fenómeno, y aún a costa de la rigidez que siempre comportan los encuadramientos, propone una división en cuatro grupos que acogen un amplio abanico que abarca desde lo profesional hasta lo ejemplarizante, pasando por las más comunes cuyo fin es la caridad, sin olvidar las estrictamente relacionadas con la actividad parroquial ${ }^{3}$. Las primeras quedarian reservadas a los miembros de alguna actividad laboral: vinateros, panaderos, curtidores, comerciantes de trigo, etc, y serían, por tanto, las que darían mayores problemas a la hora de identificarlas como tales cofradías, por la similitud con los gremios, tal como ya se dijo ${ }^{4}$. En segundo lugar se encuentran aquellas congregaciones que tienen una función edificante ante la sociedad por la finalidad santificadora de los hermanos cofrades, bien por medio de la oración en común que estos practicaban o bien a través de diversos grados de penitencia llevados a cabo por los mismos ${ }^{5}$. Las llamadas cofradías caritativas, engloban en su seno a todas aquellas cuya función principal consiste en la regencia y mantenimiento de alguna institución hospitalaria o caritativa para acoger enfermos, huérfanos o peregrinos; así como en la práctica habitual de la caridad hacia los más necesitados por medio del cuidado o de la limosna. Finalmente, se completa la clasificación con las cofradías parroquiales. Entre sus misiones más propias destacan la ayuda a las actividades parroquiales enfocada a cuestiones materiales como el cuidado general del templo, la ornamentación del mismo para las fiestas o la ayuda durante las procesiones. Por otra parte no se puede olvidar la inclusión en este grupo de aquellas congregaciones que dentro de una parroquia centraban su interés en las reliquias conservadas dentro del tesoro parroquial o aquellas otras que se dedicaban a una determinada advocación que, podía variar entre la más comunes que corresponderian a las dedicadas al Santísimo Sacramento o las que veneraban a los patronos locales. En conclusión todas las cofradías

\footnotetext{
'Un trabajo muy interesante, en este y otros aspectos, es el análisis que realiza Gregoria Cavero Dominguez., Las cotraaías en Astorga durante la Edad Media. León. Universidad de León. 1992.

${ }^{3}$ Delaruelle, E., La pieté populaire au moyen âge. Turin, 1980.

- Sobre las diferentes actividades laborales acogidas a esta tipología de cofradía han publicado sus estudios entre otros: Blázquez Garbajosa, A., El señorio episcopal de Sigüenza. Guadalajara. 1988; y Perdrizet, P.: Le calendrier parisien à la fin de moyen âge. París, 1933.

${ }^{5}$ Estas cofradias en su variante de disciplinantes han sido estudiadas por Blázquez Garbajosa, A.: “La cotradía de la Santa Vera Cruz de Palazuelos". Cuadernos de Etnología de Guadalajara, 20 $\left(1991,4^{9}\right)$, pp.7-48.
} 
medievales buscaban en primer lugar la salus animarum de sus miembros aunque lo hicieran por diferentes caminos ${ }^{6}$.

Durante la Edad Moderna, no sólo no disminuyó sino que continuó aumentando la fundación de cofradías, gracias al impulso desmedido que supusieron las conclusiones del Concilio de Trento, de modo que desde finales del siglo XVI y durante los siglos XVII y XVIII se puede afirmar que la mayor parte de las ciudades y villas hispanas poseían una cofradia. Para esta época postconciliar, y aún con el riesgo de contradecir la clasificación aplicada, debemos destacar la acepción que el Diccionario de Autoridades, redactado en época moderna, otorgaba para el término cofradía por medio de la siguiente definición: "Congregación o Hermandad que forman algunos devotos para exercitarse en obras de piedad y charidad"?. De lo que se puede deducir que la mayor parte de las cofradías nacidas en los siglos antedichos habían derivado su finalidad hacia objetivos más concretos, es decir, que, en su mayor parte, respondían al perfil de las dedicadas a las actividades benéficas. Más recientemente, la definición de Sánchez Herrero apuesta por la caridad y la hermandad como la base de la constitución de las mismas, sin olvidar el acrecentamiento del culto público: «asociaciones de fieles, pertenecientes o no a un mismo gremio que se unen para diversos fines (profesionales, sociales, caritativos, piadosos o penitenciales) y que se suelen regir por un estatuto o reglamento" ${ }^{8}$.

\section{METODOLOGÍA}

El análisis y edición de los textos sobre las cofradías cristianas habia planteado algunos problemas a los investigadores de antaño hasta que a mediados del siglo pasado Le Bras, para resolver aquellas dificultades, propuso una metodología de aplicación a dichas fuentes que él mismo puso en práctica en posteriores investigaciones con excelentes resultados. La evolución en los estudios sobre todo tipo de congregaciones han segui-

\footnotetext{
${ }^{6}$ Para un estudio en profundidad de las cofradias medievales son indispensables a pesar del paso del tiempo las obras de los grandes clásicos de los que destacaremos una pequeña selección: Deschamps, M.: Les confréries du moyen âge. Bordeaux, 1958. Cambiaso, D., "Statutti della compagnia di San Francesco a Borgonovo (Genova) 1482». AFH, XVIl (1924), pp. 369-377. Duhr, J., “La contrérie dans la vie de l'eglese". RHE, XXXV (1939), pp. 437-478. Meesserman, G., "Les confréries des disciplinés de Sainte Dominique». Archive Frat. Pred. XX (1950), pp.21-63; "La riforma de la confraternitá laicali in Italia prima del Concilio de Trento". En Problemi di vita religiosa in Italia nel Cinquecento. Padova, (1960), pp. 17-30; y “Two unknow Confraternity Letters of St. Bernard". En Citeaux in de Nederlanden VI (1975), pp. 174-178.

'. Diccionario de Autoridades. Madrid. Editorial Gredos. 1969.

¿ Sánchez Herrero, J., "Cofradias, hospitales y beneficencia en algunas diócesis del valle del Duero. Siglos X!V y XV». Hispania. Madrid, XXXIV, 126 (1974), p. 8.
} 
do, con pequeñas variantes, aquellos primigenios trabajos ${ }^{9}$, llegándose a realizar en nuestro país publicaciones que reúnen importantes corpus documentales de reglas de hermandades y cofradías, como el recientemente publicado por la Universidad de Huelva, y en el que han colaborado un grupo de especialistas en el tema ${ }^{10}$.

Uno de los puntos más destacables para la investigación de la fundación, actividades y objetivos de una cofradía pasa por el conocimiento de sus estatutos, constituciones u ordenanzas, porque suponen uno de los primeros eslabones en su devenir organizativo. Los estatutos de las cofradías constituyen, según Trenchs y Cárcel, el tercero de los estadios documentales en la producción escrita de las mismas, tras el acta de fundación y los libros de matrícula"1.

Por otro lado son infinitos los apoyos prácticos que se pueden lograr, por medio de la documentación de archivo, para la reconstrucción de la historia de dichas congregaciones, pues la citada documentación pasa por una variedad y complejidad manifiesta, tal como se ve en el estudio de López Gutiérrez y Rodríguez Mateos sobre los archivos de las hermandades religiosas $^{12}$. Desafortunadamente han sido muchas las cofradías, y ésta que aquí se estudia es un ejemplo palpable, que no han tenido la previsión de custodiar la documentación emanada por las mismas y se ha perdido o dispersado en el transcurso del tiempo, de modo que para algunos casos, tal como el que nos ocupa, la escasas noticias que poseemos pasan únicamente por el conocimiento de las constituciones fundacionales que afortunadamente se han conservado, gracias a que en su día fueron recogidas por los archivos diocesanos que se han reservado el papel de grandes recopiladores de la documentación proveniente de las escribanías parroquiales. Estas últimas, han custodiado muchas veces entre sus documentos, los relativos a las cofradías locales.

\footnotetext{
${ }^{9}$ Como ejemplo de metodología aplicada a dichos estudios: Trenchs Odena, J., y Cárcel Ortí, M⿻ M., "Notas en torno al estudio de las cofradías medievales y modernas: La Cofradia del Santísimo Cristo de la iglesia del Salvador de Valencia (1616-1618)", Annals. Institut d'Estudis Comarcals I'Horta Sud. 3 (1984). Recientemente el piofesor Saúl Antonio Gomes ha publicado dentro de esta línea metodológica: $O$ livro do compromisso da confraria e Hospital de Santa María da Vitoria da Bataiha. Leiria, 2002.

10 Sánchez Herrero, José (Ed.). CXIX Reglas de Hermandades y Cofradias andaluzas. Siglos $X I V, X V$ y XVI. Huelva, Universidad de Huelva. 2002.

". Trenchs Odena, J., y Cárcel Ortí, M$M^{a}$ M., op. cit.

i2 López Gutiérrez, A. J. , y Rodríguez Mateos, J., Los archivos de las hermandades religiosas. Sevilla. GEA. 1993.
} 


\section{LA ESCLAVITUD DEL SANTISIMO CRISTO DEL CALVARIO}

\section{ANÁLISIS DIPLOMÁTICO}

La fuente que se presenta son las constituciones $u$ ordenanzas fundacionales de la Esclavitud del Santísimo Cristo del Calvario de Mondéjar (Guadalajara) fundada en 1765. Aparecida en un expediente organizado por el Arzobispado de Toledo ante la solicitud de aprobación de los estatutos de la misma, tiene un soporte en papel con unas medidas de $200 \times 250$ $\mathrm{mm}$ y las marcas de agua propias de la época ${ }^{13}$. El conjunto de los documentos presentados en el proceso administrativo alcanza 25 páginas, sin que éstos conformen cuadernillos, pues se trata de los originales que se presentaron en su momento, y que hoy aparecen unidos en forma de expediente cosido con cáñamo. Se desconoce si todo este proceso se registró en algún libro creado para ello, tal como nos indica la profesora Cárcel Ortí para tales procedimientos en el reino de Valencia ${ }^{14}$

La escritura es la típica humanística de fines del siglo XVIII. Entre sus características más definitorias se pueden observar un ductus ligeramente inclinado a la derecha, así como algunas cuestiones gráficas que se destacan a continuación: los redobles de letras entre los que se observan como más habituales los de $\mathbf{t}$ doble ${ }^{15}$, o la confusión entre $\mathbf{c}$ y $\mathbf{z}$, sobre todo delante de las vocales e, $\mathbf{i}^{16}$; también es equívoco el uso de $\mathbf{i}$ e $\mathbf{y}^{17}$; entre $\mathbf{b}$ y $\mathbf{v}^{18} ; \mathbf{y}$ asimismo entre $\mathbf{n}$ y $\mathbf{m}$ antes de $\mathbf{b}$ y de $\mathbf{p}^{19}$, o el uso de $\mathbf{q}$ por c sobre todo para el sonido $\mathbf{c u}^{20}$; o el empleo de $\mathbf{h}$, después de $\mathbf{p}, \mathbf{t}$ y de $\mathbf{c}^{21}$, sin olvidar la aplicación errónea de la $\mathbf{h}$ o su ausencia indebida en otras palabras ${ }^{22}$. Por lo que respecta a las abreviaturas estas se manifiestan generalmente por medio de letras sobrepuestas.

${ }^{13}$ Archivo Diocesano de Toledo. Carpeta Guadalajara 2. Expediente 12.

14. Cárcel Ortí, Ma. Milagros., "Aportación al estudio de las cofradias valencianas del siglo XVI: La cofradía de la sangre de Alcoy", En Corrientes culturales en la Valencia del siglo XVI (15501600). Valencia (1983), pp. 391-399; y "Capítulos de la Cofradía de la Sangre de Cullera", Quaderns de Sueca, III, (1982), pp. 81-93.

${ }^{15}$ Para palabras como: conttenidas, perpettuidad, presentto, santto, consttituciones, depositto, Vizentte, thenientte, renttas, éstta, efecttos, Casttellanos, Vallestteros, Cayettano, certtificación, justta, prettensión, o testtimonio, por hacer un somero balance de las empleadas.

${ }^{16}$ Para palabras como: solizite, nezesario, diligenzia, juezes, arzipreste, funziones $u$ ofrezer, entre otras muchas.

${ }^{17}$ Presentamos algunas: veyntte, Caio (nombre propio), cuio, apoio, traiendo, aia, mui.

${ }^{19}$ Sirvan como ejemplo: Calbario, prebias, promober, esclabos, biereis, aprovación, bean, nobena, .vastará, abiso.

${ }^{19}$ Destacan: yncombeniente, amvos, tamvién.

${ }^{20}$ Se pueden observar: cinquenta, quatro y quando.

" Podemos ver entre otras: thalen, thenientte, catthólica, Christo, christiano, Phelipe.

${ }^{22}$ Como representativas: aogos, hermita, hedades, onrra, hacompañándole, deshuniones. 
Tipológicamente el expediente contiene todos los documentos expedidos en el proceso diplomático seguido en la escribanía de la curia arzobispal ante la recepción de la solicitud de los mondejanos. El primero de los documentos es una carta del procurador Cayetano Rodríguez Bermejo que se presenta en nombre del cura párroco de Mondéjar y del resto de los futuros hermanos de la congregación que pretenden la aprobación de la citada esclavitud. El segundo de los diplomas lo realiza el secretario de la curia, Jacinto Marinas, que solicita se emita un informe por parte del visitador eclesiástico de la zona de Mondéjar,

"Informe el visitador... si de su aprobación se sigue algún incombeniente o perxuicio a la Dignidad Arzobispal o al derecho parroquial..."

A continuación encontramos el informe de carácter positivo realizado por el doctor Alfonso Merino, visitador del partido de Mondéjar, quien considera dichas ordenanzas sujetas a las normas establecidas por los sínodos:

"... mui conforme con constituciones sinodales y que de su aprovación no se sigue perjuicio alguno ...»

El siguiente documento es la carta de poder notarial entregada por los representados a Cayetano Rodríguez. Dicha carta presenta una invocación verbal: "In Dei nomine», para seguir con la notificación general que se acompaña de la autocalificación del documento: "Notorio sea a los que el presente poder vieren ....." . La partícula "como" da entrada a la intitulación notarial y a la cláusula corroborativa que nos deja constancia de la presencia del autor y de los testigos.

"...ante mi el presente notario apostólico, vezino de esta villa de Mondéjar, $y$ de los testigos infraescriptos..."

Sigue a continuación un largo expositivo que contiene la extensa nómina de los asistentes representados que se encuentran formalmente constituidos en el momento de la conscriptio documental que se completa con una justificación de los motivos que les han llevado a la solicitud de la aprobación de estas constituciones, así como las fórmulas de otorgamiento del poder:

"... ese mismo le damos $y$ otorgamos en todas inzidencias y dependenzias, anexidades y conexidades, libre y tranca y general administración y con clausula de que le pueda substituir en quien le pareziere, rebocar los substitutos y nombrar otros de nuevo..." 
La disposición notarial lleva implícita la datación:

"En cuio testimonio asi lo otorgamos en esta villa de Mondéjar en doze días del mes de septiembre de mill setezientos sesenta y cinco"

Las validaciones, que se presentan muy completas y se cubren por medio de las rúbricas de los presentes, signo del notario, refrendo del mismo y, finalmente, el testimonio de testigos por aquellos que no saben firmar, cierran este poder. Significamos una de las cláusulas para que sirva de resumen práctico validatorio:

"Yo el dicho Vicente Alphonso Domínguez, notario Apostólico y vezino de esta villa de Mondéjar, presente fuy a todo lo que dicho es, y en feé de ello lo signé y firmé, día de su otorgamiento".

A continuación se encuentran las constituciones que comienzan por un largo preámbulo que deja a la voz de los profetas David, Ageo y Oseas, los cuales exponen la justificación del nacimiento de la hermandad y su desarrollo en las citadas ordenanzas por medio de una relación de castigos previos por parte de Dios y el remedio en el culto y las alabanzas al Señor.

Cada una de las treinta y siete ordenanzas suponen otras tantas entradas dispositivas que conforman el objetivo por el que emana el documento. La data y la validación por medio de suscripción y rúbrica de todos los otorgantes, junto con una mínima enmendatio cierra estas constituciones.

\section{ORÍGENES Y FUNDACIÓN DE LA ESCLAVITUD}

La situación geográfica de la villa de Mondéjar, en la esquina sureste de la provincia de Guadalajara, entre las actuales provincias de Cuenca y Madrid, de cuyas capitales dista apenas 45,140 y 80 kilómetros respectivamente, es absolutamente privilegiado. Se encuentra enclavada en una loma situada en las cercanías de! valle del río Tajuña, salida natural de toda la comarca hacía el camino de Valencia, que hacen de ella un lugar de paso obligado para comerciantes de todo tipo.

Mondejar fue tomada a los musulmanes por Alfonso VI en el año $1085^{23}$. Doscientos años después, Sancho IV la entregaba en señorío a su merino

23. Para un estudio en profundidad de la Alcarria Baja en la Edad Media se puede consultar: Ballesteros San José, Plácido y Murillo Murillo, R., Aproximación histórica a la Alcarria Baja. Tierras de Zorita y Almoguera. Guadalajara: Excma. Diputación de Guadalajara. 1985 
mayor Fernán Ruiz de Biedma, junto con la merced real de celebrar un mercado franco todos los jueves ${ }^{24}$.

A mediados del siglo XV, la villa fue motivo de un largo pleito entre Catalina Lasso Carrillo e Iñigo López de Mendoza, que fue resuelto bastantes años más tarde cuando los Reyes Católicos le vendieron la villa a este último el 12 de enero de 1487. De esta manera quedaba ligada a uno de los linajes más importante de aquellos momentos: La familia Mendoza. Iñigo López que pronto se puso manos a la obra para favorecer a su nueva posesión mandó construir dos edificios de valor singular para la historia del primer arte renacentista español: el convento de San Antonio Extramuros y la iglesia parroquial de Santa María Magdalena, obras ambas ligadas al arquitecto Nicolás de Adonza ${ }^{25}$. Pocos años más tarde durante la regencia de Fernando de Aragón fue creado el marquesado de Mondéjar para Iñigo López. La voluntad testamentaria de este Mendoza, que también fue segundo Conde de Tendilla, le llevó a dejar unas mandas por medio de las cuales se pudiese terminar una ermita extramuros bajo la advocación de San Sebastián que pasado el tiempo serviría para acoger la imagen del Cristo crucificado al que honraría la cofradía objeto de este análisis ${ }^{26}$.

Llegados al siglo XVIII la salud económica de la villa se mostraba excelente, anticipando una vocación comercial y fabril que se ha confirmado en los siglos posteriores. Las familias López Soldado y Saavedra Guzmán, entre otras, amasaron capitales que les permitieron destacar en la vida cultural y eclesiástica del momento. Así pues, esta villa de señorío que seguía detentado por el marqués de Mondéjar, poseía un bienestar que realzaba su capitalidad comarcal que, aunque nunca pasó de ser plenamente ficticia siempre se manifestó como realmente efectiva, dejaba entrever la presumible apetencia que tendría el destino de la rectoría parroquial por los beneficios que llevaba anejos dirigir la parroquia de una villa con el vigoroso dinamismo que presentaba la economía de la misma.

El arcipreste de Mondéjar, Julián de Arévalo y Zuazo, se nos presenta como uno de los principales artífices de la fundación de la Esclavitud del Santo Cristo, pues encabeza la nómina de fundadores y redactores de las constituciones que se llevaron a cabo el 25 de julio de 1765 y se expusie-

\footnotetext{
${ }^{24}$ Según se indica por Anastasio Fernandez Jiménez en su, Historia de Mondéjar. Mondéjar. Ayuniamiento de Mondéjar. 1988. p. 9.

${ }^{25}$ Ambos monumentos, dado su valor pionero, estan conveniente estudiados por diversos autores. Destacaremos el análisis de Muñoz Jiménez, José Miguel, La arquitectura del manierismo en Guadalajara. Guadaiajara: Excma. Diputación de Guadalajara. 1987.

${ }^{26}$ Tenemos noticias de al menos dos testamentos emanados de Iñigo López, uno en Estremera el día 5 de mayo de 1489 y el segundo, mucho más tardío, datado en Granada el 18 de julio de 1515. En ambos se hace referencia a la ermita de San Sebastián y su terminación a costa de una serie de bienes que dejaría para eilo. López Villalba, José Miguel., "Los Judíos de Mondéjar", Cuadernos de Etnologia de Guadalajara. 17-1 (1991), pp. 9.
} 
ron al señor cardenal de Toledo, para su aprobación, por medio de un poder de fecha 12 de septiembre del mismo año. El citado poder es encabezado a su vez por Julián de Arévalo, como otorgante principal, y se encuentra extendido a nombre del procurador Cayetano Rodríguez Bermejo. El arcipreste Arévalo representa, dentro del ejercicio pastoral, el dinamizador de la cura animarum que además incentiva un proyecto de sociedad de socorros endógenos, ya que los principales destinatarios son los propios cofrades, aunque siempre dentro de los principios religiosos de la societas cristiana.

Es por ello que pudiendo resultar curioso que, lejos ya del fervor general de piedad y sensibilización popular que despertó el Concilio de Trento a finales del siglo XVI, no lo sea que un grupo de feligreses desease crear una cofradía con el explícito nombre de Esclavitud del Santísimo Cristo, ya que hoy se tiene clara conciencia de lo que representaban este tipo de cofradías devocionales, cualquiera que fuese el nombre que eligiesen para designarlas. En realidad eran un combinado de práctica religiosa devota hacia la advocación elegida, que en su mayor parte se quedaba en la preparación de las fiestas solemnes, es decir, la exteriorización de la devoción; y una congregación de socorros mutuos para alivio de los propios cofrades en sus necesidades más perentorias ante la enfermedad, pero sobre todo ante la muerte, por medio de los servicios post mortem. Estas actuaciones consistentes en acompañamiento en la eventual desgracia, funerales y oraciones, eran el reclamo más poderoso para el ingreso en la cofradia; el resto se componía de actividades de carácter social, tales como: participación en procesiones, asistencia a oficios religiosos y celebración de todo tipo de festejos devocionales hacia la advocación de la hermandad.

Aún con todo, los fundadores justifican la promoción del culto a la imagen del Santo Cristo crucificado por las circunstancias desafortunadas que habían llenado de penuria las haciendas de la comarca y por tanto de los vecinos de la villa de Mondéjar por la escasez de las cosechas y que, según los fundadores, dicho infortunio no sólo no debía llenar de tristeza a los habitantes de la villa sino que debía ser la mecha que encendiera el fervor de los corazones piadosos. Para ello en la introducción a las constituciones hacen mención, tal como se dijo, a las palabras de tres profetas, David, Ageo y Oseas. El primero recuerda que cuanto mayor sea el afligimiento más deseada debe ser la cercanía al Señor, y es por ello que en esos momentos de tribulación es cuando se debe ensalzar y glorificar el nombre de Cristo con mayor vehemencia. Por medio del segundo profeta, se nos recuerda que el Señor enojado por las iniquidades de los hombres ha puesto un candado al cielo para que no reciba la tierra el preciado don de la lluvia; $y$ finalmente Oseas nos dice que tal castigo se llevará a cabo secándose los campos y talando las viñas.

Finalmente plantean un jeroglífico, tan al gusto de la época barroca, por medio del cual escenifican una esclavitud de veinticuatro ancianos que con 
sus rezos han conseguido mudar en dócil cordero a un fiero león. Según la interpretación que los propios autores realizan a continuación, el león es Cristo crucificado que lucha como tal león contra sus enemigos, pero que como cordero piadoso ayuda a los que le imploran. Por ello, enterado de las intenciones de los habitantes de Mondéjar de fundar una esclavitud para honrarle convenientemente, Jesús les había consolado en su aflicción por medio de una copiosa lluvia.

De este modo se puede suponer que dicha escasez que había llevado a un selecto grupo de vecinos a fundar la congregación dedicada a las actividades antedichas, contase con el apoyo popular en lo que a la primera parte de las mismas se refiere, es decir, la actividad religiosa. El grupo fundador constaba de sesenta y dos vecinos procedentes de diversos estamentos y todos ellos de sexo masculino. Además del cura párroco de la villa, Julián de Arévalo y el beneficiado de dicha iglesia, Eugenio López Soldado, el conjunto estaba dividido en tres grandes grupos sociales. El grupo de hijosdalgo, el de miembros más importantes del común y el de los vecinos representantes del estado general. Al primero de los mismos pertenecían Julián Saavedra, Félix López Soldado, Jerónimo Ramírez de Arellano, Antonio Gutiérrez del Pozo, Fernando Apolinar Urbano, Nicolás Escudero, Antonio Vicente de la Plaza, Antonio Moreno, prior de la villa, Bernardo Sánchez Céspedes, clérigo de primera, Juan Manuel Eusebio, alcalde ordinario, Alfonso Ocaña, alcalde ordinario, Manuel Rodríguez de Arellano, regidor, Nicolás de Torres, regidor, Gabriel Ramiro, regidor, Juan Saavedra y Guzmán, principal síndico, Francisco Gutiérrez de Vegas, teniente administrador, Luis López Soldado, Dionisio Gutiérrez del Pozo, José Cayo López Soldado, Eugenio López Soldado, Juan López Soldado, José López Soldado y Salcedo y Pedro Alcántara López Soldado. En el grupo de los miembros capitulares del común encontramos a Francisco Saavedra y Guzmán, Francisco de la Plaza, Nicolás Camacho, Juan Moreno, Francisco Jiménez Beltrán, José Moreno, Alonso Maroto, Bernardo Aybar, Dionisio Camacho, Francisco Ribera, Manuel Moreno, Vicente de Torres, Cayetano de Torres, Vicente Alfonso Domínguez, Juan Francisco Polo Gutiérrez, escribano real, y Francisco Castellanos. Por el estado general: Nicolás Fernández, Antonio García Martínez, Juan Lucas García Martínez, Sebastián de Rueda, Melchor Martínez, Gabriel Ballesteros, Francisco Segovia de Felipe, Felipe Segovia, Francisco Segovia de Juan, Antonio Quintana, Juan Dieguez, Juan de Dios de Legäzpi, Francisco Jiménez Alcalde, Manuel de Guevara, Alonso Segovia de Felipe, Francisco Jiménez de Barrera, Bartolomé Fernández, Andrés Fernández, Alfonso López Hontoba, Bernardo Pérez y Manuel de Segovia de Felipe.

Se puede deducir una cierta diversidad económica o social, pero con unos límites, ya que aunque en las constituciones se admitía a todo tipo de personas de cualquier sexo, edad, estado o condición, había que excep- 
tuar, tal y como era habitual en la época, a aquellos que tenían antecedentes familiares de judíos o moros; o que por alguna otra cuestión hubiesen tenido algún tipo de actuación que hubiese derivado en problema con el Santo Oficio que les llevase a quedar restringidos en su acceso:

"Por quanto todos somos obligados al Señor, que sin eszepción de personas se ofreció en sacrificio...” 27

"los que hubiesen de admitirse por esclavos han de ser descendientes de christianos viejos limpios de toda mancha y traza de ..." ${ }^{28}$

Por lo tanto, si exceptuamos los límites impuestos por cuestiones religiosas, la Esclavitud de Mondéjar, quedaría en apariencia como una cofradía bastante abierta, pero si profundizamos en la lectura de las constituciones veremos que se introducen frases muy significativas en lo que respecta a la cuestión de los sexos de los integrantes de la misma:

"en este turno para el servizio de maiordomía no entrarán las mujeres, como tampoco en las juntas ni en cosa impropia de su sexo... ${ }^{29}$ rera..." 30

"pero el señor abad podrá nombrar a alguna de las esclavas por cama-

Las mujeres quedaban excluidas de los cargos y lo que era más grave, de la asistencia a los cabildos de cofrades por medio de estas disposiciones. Asimismo quedan en desigualdad por la sutilidad en la redacción de las ordenanzas que siempre aparecen dirigidas a los hombres o por las alusiones que se realizan a los cofrades varones. Las ocasiones en que intervienen mujeres en alguna actividad se nos manifiestan como una excepción. Se puede ejemplificar esta marginalidad a que se vio sometido generalmente el género femenino en la fundación y mantenimiento de cofradías recurriendo al estudio que Blázquez Garbajosa hace de la cofradía de la Santa Vera Cruz de Palazuelos, donde llega a documentar que en la citada hermandad se habian afiliado cincuenta personas desde 1561 a 1562 , pero a efectos contables solo figuraban cuarenta, sobre este desfase nos dice: “La explicación de esta aparente anomalía es fácil: las diez mujeres inscritas no son tenidas en cuenta en el cómputo de los primeros co-

\footnotetext{
27. 27 Constitución $1^{\text {a }}$.

28. Constitución $2^{3}$

${ }^{29}$.Constitución $15^{\mathrm{a}}$.

${ }^{30}$.Idem.
} 
frades afiliados ${ }^{31}$. Doscientos años más tarde continuaba la marginalidad de la mujer, si exceptuamos las viudas de los cofrades o casos extraordinarios, en la fundación y mantenimiento de este tipo de hermandades religiosas, quedando materializada documentalmente sin ningún tipo de ambages como se acaba de ver.

\section{FINES DE LA HERMANDAD}

Este tipo de congregaciones se fundaban para proceder al culto y veneración del Santísimo Cristo, es decir con unos fines puramente religiosos, pero sin olvidar otro de los objetivos principales en todo tipo de cofradías que es la de carácter benéfico y de auxilio mutuo entre sus miembros. Por lo tanto la finalidad que justificaba las actividades más importantes que se propuso llevar a cabo la Cofradía o Esclavitud dedicada al Santísimo Cristo del Calvario de Mondéjar fue la de conmemorar una de las solemnidades más señeras de la Santa Cruz, la de su Exaltación que se celebra el dia 14 de septiembre de cada año. En otras cofradias con celebraciones similares, y para evitar la posibilidad de que dicha fecha cayese en día laborable, lo que lógicamente sucedía con mucha frecuencia, las honras se fijaba para el tercer domingo de septiembre, tal como sucedía con la cofradía de la Vera Cruz de Azuqueca de Henares ${ }^{32}$.

La función solemne duraba tres días, durante el primero se hacian las Vísperas, el día siguiente y más importante, la Procesión desde el santuario extramuros donde se custodiaba la imagen, Misa con sermón, y finalmente, el tercer día, el Oficio para los cofrades difuntos, y de nuevo Procesión de regreso al citado santuario.

El día de la víspera de la fiesta de la Exaltación de la Cruz comenzaba por medio del traslado solemne de la imagen de Cristo crucificado desde la ermita de San Sebastián ${ }^{33}$, a la iglesia parroquial de la villa, acompañado por todos los hermanos que portaban cirios encendidos a lo largo del re-

\footnotetext{
31. Blázquez Garbajosa, Adrián., "La Cofradía de la Santa Vera Cruz de Palazuelos",Cuadernos de Etnología de Guadalajara, 20 (1991.4), pp. 7-48.

${ }^{32}$. En dicha cofradía realizaban una función solemne para la Veneración de la Cruz, pero acordaron dejarla fija. Cfr. Baras Navarro, M del Carmen, "La Vera Cruz en Azuqueca de Henares", En I Encuentro de Historiadores del Valle del Henares, Guadalajara, (1988), pp. 75-82

${ }^{33}$.La ermita de San Sebastián de Monciéjar ha sido estudiada en repetidas ocasiones debido a unas figuras de origen cesconocido que se encuentran custodiadas en diferentes estancias adosadas a la citada ermita. Dichas figuras representan diferentes escenas de la pasión y muerte de Jesús. Cfr. López Villalba, José Miguel.: "Los Judios de Mondéjar". Cuadernos de Etnología de Guadalajara. 17-1 (1991), pp. 21. Más recientemente: González de Lucas, Rafael.: "Sobre el monte Calvario de Mondéjar y los ecos de sus leyendas (algunas reflexiones literarias y antropológicas). Cuadernos de Etnología de Guadalajara. 30-31 (1998-1999), pp.457-487.
} 
corrido. Durante la procesión el estandarte del Santísimo Cristo era llevado por el hermano mayor que poseía dicha distinción por las ordenanzas, y si no pudiese hacerlo por cualquier circunstancia lo delegaba en alguno de los miembros de la esclavitud. Los mayordomos debían colocarse al lado de la imagen, dos de ellos llevaban las barbas del estandarte y los restantes portaban cirios encendidos rodeando a la citada imagen y al clero, con lo cual detentaban la categoría de alumbrantes principales.

El día de la celebración, 14 de septiembre, se oficiaban dos misas, en la primera de gran solemnidad, se daba un sermón en honor de Cristo, y la segunda, cuyo horario se fijaba la víspera, se realizaba por la salud de los miembros de la cofradía que aprovechaban durante dicha misa para cumplir con el deber sacramental de la comunión.

Para que todos los miembros de la esclavitud pudiesen concurrir con cierta comodidad a la celebración de la Eucaristía se colocaban una serie de bancos en esta disposición: Los miembros del ayuntamiento encabezados por los alcaldes se situaban en los lugares que habitualmente ocupaban. Si alguno de ellos era a su vez mayordomo o hermano mayor de la cofradía podía trasladarse si lo deseaba a los dos bancos que se colocaban para dichos cargos de la hermandad bajo las gradas del presbiterio, de modo que en el primero se sentaban los mayordomos más ancianos y en el segundo los más jóvenes, mientras que los demás esclavos se colocaban sin ningún tipo de distinción entre el resto de los asistentes a los oficios. Los hermanos de la cofradía que fuesen eclesiásticos podían permanecer en el coro con el resto de sus compañeros de oficio si lo consideraban más conveniente.

Asimismo, y dentro de las actividades que se realizaban durante aquellos dias, los miembros de la esclavitud se reunían en la ermita de San Sebastián, lugar donde se custodiaba la imagen, para rezar por la exaltación de la fe católica y de este modo conseguir la indulgencia plenaria que había concedido el Papa Clemente Xill.

El día 15, es decir, dos días después de haber salido la imagen de su santuario extramuros regresaba al mismo donde permanecía hasta el día 13 de septiemibre del siguiente año, en un proceso temporal que ha seguido hasta nuestros días. También se aprovechaba esa última jornada festiva para la honra de los hermanos difuntos por medio de un oficio rezado en la iglesia parroquial.

Ni que decir tiene que era de obligado cumplimiento para todos los hermanos de la cofradía la asistencia a los diferentes actos programados du. rante esta solemnidad, exceptuados aquellos que estuviesen enfermos 0 ausentes de la villa. Los que no pudiesen justificar la falta de asistencia eran multados con una libra de cera. 


\section{HACIENDA DE LA COFRADIIA ${ }^{34}$}

El conocimiento profundo del funcionamiento de estas cofradías pasa por el análisis de sus documentos de hacienda, puesto que su planteamiento principal era la preparación de las actividades para honrar a la advocación a la que se dedicaban y el socorro de las necesidades de los hermanos. Se trazará, por lo tanto, un perfil de los principales ingresos y gastos en la vida económica de la misma.

Las honras de Exaltación de la Cruz generaban una serie de gastos (misas, sermón, cera...) de los que estaban explícitamente excluidos aquellos que tuviesen que ver con actividades mundanas de cualquier tipo, como toros o bailes; llegándose a fijar la pena de expulsión a los cofrades que infringieran estas normas.

De los ocho mayordomos que eran elegidos cada año, siete de ellos pagaban cincuenta reales de vellón por cabeza, de modo que sumaban un total de trescientos cincuenta reales; el otro, que figuraría como hermano mayor, se hacía cargo del gasto del sermón que suponía un total de sesenta y cinco reales, y además debía llevar al prior que realizaba el sermón a su casa, por lo que se le reservaba el derecho a elegir orador, siempre con el visto bueno del abad que en esto también actuaba como cabeza visible de la congregación.

La cantidad de trescientos cincuenta reales resultaba suficiente para cubrir el resto de los gastos de la celebración que se habituaban a repartir de la siguiente forma, tal y como se recoge en la constitución décima: Había un gasto fijo por los derechos parroquiales de cura y beneficiados por todas las funciones, entre las que destacaban la misa cantada, las vísperas y las procesiones, lo que sumaba un total de treinta y seis reales, mientras que los sacristanes y campaneros por idénticas actividades cobraban cuarenta reales. Las honras costaban algo similar, treinta y dos reales, mientras que la misa rezada costaba bastante menos, solamente cuatro reales. Para la iglesia por las dos funciones se daban once reales, y finalmente el gasto mayor lo suponía la arroba de cera que se colocaba en el altar y comportaba doscientos seis reales, sin olvidar los veintiún reales que empleaban en los gastos de transportar dicha cera y pagar a los que componian el altar.

\footnotetext{
${ }^{34}$. Muchos han side los trabajos que han analizado los libros de contabilidad de las cofradías medievales y modernas. Se puede ver para las cofradías bajomedievales de la Corona de Aragón ejemplificadas en una cofradía de la capital del reino. López Villalba, José Miguel., «Estudio paleográfico y diplomático de las cuentas generales de ingresos y gastos de las cofradias aragonesas bajomedievales. La cofradía de Nuestra Señora Santa María la Mayor y del Pilar de Zaragoza", Memoria Ecclesiae, XI (1997), pp. 483-494.
} 
Por otro lado, nos aclaran estas primitivas constituciones que para el buen funcionamiento de la cofradía cada uno de los esclavos pagaba al año cuatro reales de vellón que se debían entregar el dia de la Invención de la Cruz, es decir, el tres de mayo. Como en buena lógica no todos los cofrades podrian llevar a cabo el pago en fecha tan concreta se decretaba una prórroga que finalizaba el día 14 de septiembre, festividad de la Exaltación. La limosna popular también era recogida por los miembros de la congregación el día 13 de septiembre, víspera de la fiesta, colocándose en la puerta de la iglesia para recibir los donativos de los vecinos de la villa.

En el supuesto de que una persona ajena a la hermandad desease costear ella sola el gasto de todas las honras y funciones de un año, se dejaba claro que no sólo no se le impediría, sino que se alentarían tales deseos, premiándole con la categoría de cofrade, eximiéndolo de la contribución anual con posterioridad, además de obtener todos los beneficios e indulgencias que alcanzasen los demás miembros. Por último, en el supuesto de que asistiese a la celebración, se le otorgaba en todos los actos el honor de ejercer como hermano mayor. De tal suerte que a los mayordomos nombrados para aquel año se les dejaría para que llevasen a cabo su función el siguiente, y únicamente en el caso de que ya hubiesen entregado la limosna de los cincuenta reales al tesorero se les dejaría elegir si consentían o no pasar a otro año, si no lo hacían se rogaba al donante que fuese él quien atrasase su contribución.

En la constitución decimonovena se recoge la situación de aquellos forasteros que queriendo ser hermanos tenian dificultades para llevar a cabo la contribución anual o servir la mayordomía y se especifica que por medio de un único pago de doscientos reales se eximían de una y otra carga. Pero si quisieren pagar anualmente y no pudiesen acudir a la villa a cumplir con sus obligaciones, se verían obligados a nombrar un albacea que lo hiciese por ellos y que llegado el turno de cumplir con la mayordomía asimismo la ejerciese en su nombre.

El dinero recogido por diferentes medios era siempre empleado en la realización de actividades religiosas como el pago de misas para celebración de la fiesta, las misas por los esclavos difuntos, el gasto de velas, tanto en los entierros como en el acompañamiento de la imagen o en la iluminación continuada que se hacía de la misma en el santuario extramuros en el que se custodiaba todo el año. No estaba permitido el gasto en ningún tipo de actividades laicas como toros, bailes o meriendas, lo cual quedaba terminantemente prohibido, así como en fuegos artificiales, que por orden del Cardenal de Toledo fueron expresamente prohibidos durante la celebración de la procesión e inmediatamente antes y después de la misma.

La contabilidad era llevada por el tesorero, y aunque no se tiene constancia clara de los libros en que se recogía, se entiende que serían los 
clásicos Libros Mayores o Libros de Cargo y Data de cuentas, ya que en ellos se reflejaba la actividad económica de la mayor parte de las instituciones coetáneas, por medio de asientos ${ }^{35}$. Una vez nombrado el nuevo tesorero, el saliente debía entregarle, en el espacio de un mes, el libramiento y el alcance que hubiese resultado. Si la cofradía resultaba alcanzada y el nuevo tesorero no quería seguir adelante con su responsabilidad podía dejarlo pero se veía obligado a realizar la paga.

Después de aprobadas estas constituciones primigenias de 1765 , todos aquellos que quisiesen entrar en la congregación se verían obligados a realizar una paga de once reales de vellón de entrada, además de obligarse a llevar la mayordomía si por edad les correspondiere el primer año que ingresasen.

\section{BENEFICIOS Y OBLIGACIONES}

Las cofradías religiosas de la época se manifiestan, como se ha dicho, como sociedades de socorros mutuos, al menos en los aspectos médicos y para cubrir los entierros de sus miembros, así como para la celebración de oficios en pos de la salvación del alma de los mismos. A pesar de lo dicho, las constituciones de la Esclavitud de Mondéjar exponen claramente el deseo de no beneficiar a todos los miembros de la misma de igual modo, sino proporcionalmente a las contribuciones que cada uno de ellos hubiese realizado. Todos los miembros una vez fallecidos, y por el hecho de serlo, tenían derecho a diez misas rezadas. Los que hubiesen detentado algún cargo en la congregación aumentaban sus derechos. Así los que hubiesen sido mayordomos o hermanos mayores disfrutarian de un alivio para sus almas consistente en la celebración de veinte misas rezadas, de igual modo lo recibirían las esclavas que hubiesen servido voluntariamente y los que al ingreso hicieron un único pago de doscientos reales.

Si algún año, la economía de la congregación no estuviese boyante y por falta de miembros que se hiciesen cargo de los gastos, se tuviese que costear la función por parte de voluntarios, éstos, en el aciago día de su faliecimiento tendrian, gracias a sus aportaciones, determinados beneficios en la celebración de oficios fúnebres. Si el número de voluntarios fuese de cuatro, cada uno tendría derecho a treinta misas, si fuese de tres las misas aumentarían a treinta y cinco, si fuesen en número dos o uno solamente el

\footnotetext{
${ }^{35}$. Para López Gutiérrez y Rodríguez Mateos los libros de cuentas de ingresos y gastos pueden ser verdaderamente considerados unos instrumentos de registro de la economía de las cotradías. López Gutiérrez, Antonio. J. y Rodriguez Mateos, Joaquín., idem, pp. 94-95.
} 
que lo costease, entonces las misas aumentaban hasta cuarenta. También se recoge el supuesto de los cofrades que hubiesen detentado algún cargo y lo repitiesen por turno, tendrían derecho a diez misas más.

Todo lo dicho hasta ahora se entiende cuando los miembros de la esclavitud estaban al corriente de los pagos. Podía acontecer que alguno de los hermanos hubiese pasado a un estado de lamentable pobreza y no pudiese soportar los pagos anuales, entonces se formaba una comisión de tres personas de la congregación que investigaban si realmente era cierta la situación, y llegados a esta certeza se le consideraba como si hubiese cumplido con su obligación económica, se asistía a su entierro y se celebraban las misas que por su categoría en la esclavitud le hubiesen correspondido.

El ritual al que tenían derecho los cofrades por medio del alumbramiento de velas y hachas de cera variaba en determinados casos. Destacamos, entre otros, uno especial, ya que requería un pago previo, y consistía en el acompañamiento con cuatro hachas de cera cuando se iba a dar el Santo Viático a algún hermano enfermo o cuando en el caso de haber fallecido se trasladaba el cadáver a la iglesia parroquial y posteriormente al cementerio, o mientras se realizaba el oficio de difuntos. Únicamente los cofrades que habian pagado dos ducados tenían derecho al citado acompañamiento, igualmente lo tenían aquellos que no siéndolo pagasen cuatro ducados. Sea como fuere la cuestión del alumbramiento, el traslado del cadáver siempre se hacia por medio de la compañía de todos los cofrades.

Los miembros de la esclavitud estaban obligados a una serie de actividades siempre que estuviesen sanos y en la villa cuando estas se celebrasen. Destacamos la asistencia a misa, procesiones, acompañamientos de los cadáveres de los hermanos fallecidos, funerales, juntas y otras cualesquiera actividades que fuesen organizadas por dicha cofradía. En el supuesto de que sin justificación alguna no concurriesen a las mismas eran multados, como se vio, con una libra de cera.

No era corriente la expulsión de la congregación y solamente en casos extremos se llegaba a estos términos, ya que antes de expulsar se examinaban debidamente los motivos y las presuntas actuaciones por una comisión, para que en el momento de la votación hubiese la mayor ecuanimidad posible. De cualquier forma las situaciones menos toleradas eran la malversación de fondos o el mal uso de los mismos.

\section{ELECCIÓN Y DESEMPEÑO DE CARGOS}

No queda constancia documental del ejercicio del poder general de la cofradía por medio de un cabildo o junta general de cofrades, sino que se hace alusión a una junta delegada de trece miembros, pese a ello se debe enten- 
der que existiese la posibilidad de la reunión de esta junta general ante la preparación del culto, devoción y honras de su advocación o para aprobar las cuestiones importantes, tal como las elecciones anuales de los cargos.

El nombramiento de hermano mayor y del resto de los mayordomos se hacía el día 14 de septiembre antes de la procesión. La elección de mayordomos, que eran los responsables ejecutivos de todas las actividades, se hacia anualmente en número de ocho, cuatro de entre los de mayor edad y otros cuatro de los más jóvenes. Estos últimos se podían sacar incluso entre aquellos que tenían la consideración de párvulos, siempre, claro está, con el permiso de los padres o tutores.

El cargo de hermano mayor, llamado en otras cofradías peostre, se concedia al más anciano entre los mayordomos, siempre que no hubiese un sacerdote entre los elegidos, ya que aunque fuese más joven se le tomaría para el cargo. Si hubiese más de un sacerdote se elegía entre éstos siempre al de mayor edad. El hermano mayor, dada su responsabilidad ante el ejercicio de las actividades económicas y administrativas principales, gozaba, entre otras preeminencias, la de sentarse al lado del abad durante los oficios religiosos en lugar distinguido del resto de la cofradia, y la de portar el estandarte los días de las procesiones.

En principio para todas estas elecciones se excluía a las mujeres, pero si lo solicitaban y tenían el permiso del marido podían sustituir a uno de los mayordomos jóvenes. Si había dos candidatas entonces reemplazaban a un mayordomo anciano y a uno joven. Asi hasta el número máximo de siete que no podían superar ya que el cargo de mayordomo mayor tenía que estar siempre en manos de un varón.

El número de mayordomos se podía aumentar hasta cuatro más, siempre que algunos de los miembros de la esclavitud no quisiesen esperar el turno de su edad y así lo solicitasen. De este modo quedaban exentos de servir por su turno, salvo que lo pidieran nuevamente.

Para la elección del resto de los cargos se hacia una junta general ocho días después del 14 de septiembre y en la misma se nombraban el tesorero, cuatro consiliarios, un secretario y un muliidor.

El tesorero tenía como misión principal la de guardar y administrar los caudales de la esclavitud, además de preparar los informes económicos necesarios para la celebración de las juntas y deliberaciones de cualquier tipo. Para ello llevaría los libros de cuentas con los cargos y datas.

Los consiliarios debian aconsejar y exponer su parecer en todo lo concerniente a la administración de la cofradía. Los dos más antiguos eran los encargados de preparar las generalidades de la función solemne y los cuatro en conjunto, la procesión, su cuidado y buen orden, las luces del acompañamiento y cualquier otra actividad referida a la misma desde el 
santuario extramuros donde se encontraba la imagen o su regreso una vez finalizadas las honras religiosas. Parecen tener pues una función de control general sobre aquellos aspectos que por su nimiedad escapasen al hermano mayor o a los mayordomos, sin olvidar la actuación que su propio nombre conlleva de tener presto el consejo diligente.

El secretario, por su parte, desarrollaba como función principal la conservación de la documentación que generaba la hermandad, en particular, la tenencia de los libros de actas y el levantamiento de las mismas. Tenía obligación, por lo tanto, de asistir a todas las juntas y reuniones y reflejar las mismas en el libro que para ello tenía la esclavitud. En libros separados aparecían la nómina de los hermanos y los nombramientos de cargos.

El mullidor era un oficio arcaizante, similar a los munidores de los concejos medievales, con la función de "munir» o mover a los hermanos, es decir, de avisarles para las reuniones. No es un cargo como tal sino un oficio sin sueldo que se puede aceptar por alguna persona externa a la congregación y que obtendrá como premio las prebendas como cualquiera de los hermanos. Tal es así, que si muriese en el ejercicio del cargo se le tendría a todos los efectos por hermano y obtendría el goce de los sufragios como uno más de ellos.

En el momento de la elección de estos oficios, el tesorero saliente proponía dos nombres para elegir uno. Los consiliarios proponian uno cada uno, comenzando por el más antiguo en la cofradía dentro de los de mayor edad o los de mayor dignidad de su estado, finalmente el secretario proponía a otro hermano para tal puesto. Todos los cofrades votaban en secreto de tal suerte que quedaban elegidos aquellos que obtenían mayor número de votos. El tesorero entrante siempre tenía que ser elegido entre los dos propuestos, pero los consiliarios o el secretario podían no serlo de entre los predeterminados y con el sigilo del voto secreto nominar a otros más convenientes, de modo que finalmente se determinaría a los nuevos cargos por el mayor número de votos. Por su parte el mullidor, al ser criado de la congregación, será elegido una vez y si quisiere continuar en el cargo podría hacerlo indefinidamente. Tal oficio está exonerado de pagar la limosna de los cuatro reales anuales, así como de servir la mayordomía. Pero ello no es óbice, tal como se vio. para disfrutar de los beneficios como si hubiese cumplido con sus obligaciones con la hacienda de la congregación.

La junta de la congregación no debía superar nunca el número de trece para poder funcionar con corrección y celeridad y por otro lado en una clara alusión al número que sumaban Cristo y los Apóstoles ${ }^{36}$. Su función

36. Era común que se utilizasen números simbólicos para acotar los miembros de las cofradías, como se puede ver para la cofradía del Santo Sepulcro de Sigüenza, que fijaron el número máximo de cofrades en setenta y dos por ser estos los discípulos de Cristo. Ortego Gil, P., "La Cofradía del Santo Sepulcro de Sigüenza», Cuadernos de Etnología de Guadalajara, 25 (1993), pp. 9-82. 
pasaba por juzgar y resolver todos los asuntos concernientes a la esclavitud. Entre ellos, y no era el de menor importancia, estaba el de exigir la limosna a los mayordomos y demás miembros. Por otro lado, también se ocupaban de solicitar la paga a los morosos y de cobrar las multas a los que hubiesen incurrido en ellas.

Queda por aclarar una cuestión que no se especifica en las constituciones y es la referente a la custodia de las llaves del arca de la cera. En ella se guardaba el capital donde la cofradía tenía su gran inversión, como se ha tratado en los gastos de las honras. En otras cofradias de la época se custodiaban por medio de dos llaves que quedaban en posesión del escribano y del hermano mayor ${ }^{37}$.

\section{CONCLUSIONES}

La historia de la esclavitud del Santo Cristo del Calvario se remite al acta fundacional y a las constituciones primigenias, pues infelizmente, la búsqueda de otros ordenamientos posteriores o algún ejemplar de libros de actas, contabilidad o de cualquier otro tenor, tanto en el archivo parroquial de Mondéjar ${ }^{38}$ como en el archivo diocesano de Toledo, no han dado resultados fructíferos. Se han limitado por tanto las conclusiones al momento de la fundación de la esclavitud que se presenta con un doble objetivo, uno piadoso para honrar y glorificar a Jesús crucificado por medio de la celebración de diferentes funciones los días de la fiesta de la Exaltación de la Cruz, y un segundo, de carácter social que buscará, como la mayor parte de las cofradías, dar respuesta a las necesidades más perentorias de la vida, tanto físicas, como espirituales, por medio del refugio de todo creyente en el servicio y alivio de las almas. Pero ante todo nos hallamos ante una estructura corporativa que nace como sociedad de socorros mutuos y que pretende lograr sus fines por medio del mantenimiento de una hacienda saneada a través de la limosna anual de todos lcs hermanos, además de las aportaciones extraordinarias de aqueilas personas ajenas a la congregación y poder garantizar a todos los afiliados una serie de servicios en caso de enfermedad grave o fallecimiento. En el nacimiento de la Esclavitud no disponen de un capital anterior, pues comienzan sin patrimonio ni bienes muebles o inmuebles o al menos no lo hacen figurar en las constituciones, pero si reflejan que la escasez de los primeros momentos les impedirá adquirir el estandarte y costearán unos cetros o cruces procesionales

${ }^{37}$ Blázquez Garbajosa, Adrián, Idem. p. 17

38. Esta parroquia mantiene todos sus fondos. Crr. López Villalba, José Miguel., "Catálogo del archivo parroquial de Santa María Magdalena de Mondéjar (Guadalajara)", Wad-al-Hayara. 21, (1994), pp. 321-342. 
mientras tanto ${ }^{39}$. Es de entender que con el tiempo la cofradía crearía un patrimonio significativo basado en las mandas de los testamentos de los cofrades más beneficiados por la fortuna, que de esta forma asegurarían al modo medieval, es decir, a través de unas donaciones de índole espiritual, una serie de oficios religiosos post mortem.

En resumen, un compromiso de mutualidad, de sentimiento de compañerismo inter pares, cubierto de un eminente sentido práctico de auxilio material o espiritual de los miembros necesitados, alejado del sentimiento de solidaridad que presentan otras sociedades religiosas anteriores y contemporáneas hacia lo exógeno, y por ello suelen dejar algún apartado para la preocupación social hacia los colectivos ajenos a la cofradía: pobres, niños huérfanos, doncellas, viudas, etc, con la creación o mantenimiento de institutos caritativos, albergues $u$ hospitales que servirían para acogida 0 ayuda a estos colectivos desfavorecidos por la fortuna; o bien creando un fondo hacendístico para resolver los problemas que nacen en el universo cotidiano de la desgracia humana. No se debe olvidar que el fenómeno de las cofradías supuso una forma de asociación voluntaria que representó todo un mundo de transmisiones de la piedad y la caridad, pues fue el abanderado en el comportamiento social ante la pobreza ${ }^{40}$.

La cofradía analizada se sustenta en el dinamismo económico que presenta la villa de Mondéjar a fines del siglo XVIII. Es el reflejo de una sociedad en crecimiento, aún por encima de las desgracias climatológicas que parecen abatir sus haciendas. Su carácter de estructura de representación debe salvaguardar un aspecto de carácter simbólico de gran importancia, la advocación a un patrono que en este caso, sobrepasa la titularidad común de los que habitualmente suelen presentar estas asociaciones, pues acostumbraban a someterse al amparo de los patronos locales. La Esclavitud se encomienda a Jesús crucificado, ahí acaba la retórica formalista y el aspecto iconográfico y da comienzo la realidad corporativa, basada en la solidaridad, mágica palabra, que condicionará la acción desplegada por la cofradía. Es decir, estamos ante una corporación devocional regida por un ordenamiento normativo estructurado y convenientemente sujeto a la vertiente de caridad mutua entre miembros de la misma, que queda muy lejos de las palabras de San Pablo a los corintios: "Aunque yo tenga el don de la profecia y conozca todos los misterios y toda la ciencia; aunque posea la fe con toda plenitud, hasta el punto de mover montañas, si no tuviese caridad, nada soy ${ }^{41}$.

${ }^{39}$ Constitución $24^{z}$.

${ }^{40}$. Aunque muchos han sido los autores podriamos destacar dos obras plenamente clarificadoras y ya clásicas en el panorama de la beneficencia y de las cofradías, para la primera de las cuestiones: López Alonso, Carmen., La pobreza en la España medieval. Madrid, 1986; para la cuestión segunda: Hevia Vallina, Agustín., "Las Cofradías en la vida de la Iglesia: un mundo de comunicación para la piedad y la caridad. Hacia un censo de documentación de cofradías de la iglesia en España», Memoria Ecclesiae, 1. Barcelona, (1990), pp. 77-109.

"I Corintios 13, 1-2. 


\section{APÉNDICE DOCUMENTAL ${ }^{42}$}

\section{DOCUMENTO № 1}

\section{[1765, septiembre. Mondéjar]}

Carta de Cayetano Rodríguez Bermejo al Excelentísimo Señor Arzobispo de Toledo presentando un poder de Julián Arévalo y Zuazo, cura párroco de Mondéjar, y de los futuros hermanos de la Esclavitud del Santísimo Cristo del Calvario de Mondéjar, junto con las constituciones de la cofradía que pretenden fundar.

Archivo Diocesano de Toledo. Serie: Guadalajara 2. Expediente 12. Papel. 1 hoja. $200 \times 250 \mathrm{~mm}$. Buena conservación.

\section{Excelentísimo Señor ${ }^{43}$}

Caietano Rodríguez Bermexo en nombre de Don Julián Arévalo y Zuazo, arcipreste y cura propio de la Yglesia Parroquial de la villa de Mondéjar y demás personas contenidas en el poder que presento y en virtud de él parecco ante Vuesa Eminencia como más aia lugar y digo:

Que mis partes han fundado una congregación o esclavitud dedicada al Santísimo Christo con el título del Calvario, que se venera en la Hermita del Santo Sepulcro de la adbocación de San Sevastián Extramuros de dicha villa y parroquia, su buen régimen, gobierno y perpetuidad han hecho las constituciones y ordenanzas que presento y para que se obserben guarden y cumplan.

A vuesa eminencia suplico, aia por presentadas las dichas ordenanzas y se sirba en su vista aprobarlas y confirmarlas, en todo y por todo, según y como en ellas se contiene, y para que los indibíduos que son y fueren de dicha esclavitud las obserben guarden y cumplan, librar el despacho necesario en que recibirán merced, et çétera.

Bermexo. (Rúbrica)

${ }^{42}$. En el desarrollo dei apéndice documental se ha respetado el orden archivístico que presenta el expediente, aún a costa del posible orden cronológico, para no desbaratar el principio de procedencia. $\mathrm{N}$, del A.

43. En el margen superior izquierdo puede leerse: "Año 1765 « y en el derecho: "Mondéjar. Ordenanzas de la Esciavitud del Santísimo Christo del Calvario". Ambas presentan escrituras posteriores a la confección del documento. 
1765, septiembre, 20. Toledo.

Orden de Jacinto Marinas, secretario de la curia arzobispal, al visitador eclesiástico del partido de Mondéjar para que aclare si se pueden aprobar las constituciones propuestas por los fundadores de la Esclavitud del Santísimo Cristo del Calvario.

Archivo Diocesano de Toledo. Serie: Guadalajara 2. Expediente 12. Papel. 1 hoja. 200×250 mm. Buena conservación.

Toledo, y septiembre 20 de $1765^{44}$.

Informe el visitador del partido de Mondéjar en vista de las ordenanzas que se presentan, si de su aprobación se sigue algún inconveniente 0 perxuicio a la Dignidad Arzobispal o al derecho parroquial, y si ay en aquella iglesia alguna otra cofradia o hermandad con la adbocación de esta. Y lo remita a este consejo de su Eminencia el cardenal, mi señor Jacinto Marinas. Secretario.

${ }^{44}$. En el margen izquierdo superior está escrito: “Señores. Carrasco, Sánchez, Montero, Palmero". 
DOCUMENTO № 3

1765, octubre, 2. Alcalá de Henares.

Informe positivo de Alfonso Merino y Torres, visitador eclesiástico del partido de Mondéjar, sobre la conveniencia de las ordenanzas de la Esclavitud del Santísimo Cristo del Calvario de esa villa.

Archivo Diocesano de Toledo. Guadalajara 2. Expediente 12. Papel. 1 hoja. $200 \times 250 \mathrm{~mm}$. Buena conservación.

Informe.

Excelentísimo Señor.

En cumplimiento de lo que por vuestra eminencia se me manda por su decreto de veinte de septiembre próximo pasado y haviendo reconocido con toda reflexión y cuidado las ordenanzas echas para el buen régimen y gobierno del Santo Christo del Calvario de la villa de Mondéjar, descubro estar con el maior arreglo para el vien espiritual de los Hermanos y culto de su Divina Magestad y precavidos los yncombenientes y abusos que se suelen originar, en semejantes hermandades, mui conforme con constituciones sinodales y que de su aprovación no se sigue perjuicio alguno a la dignidad de Vuestra Eminencia ni al derecho parroquial, ni hay otra cofradia con esta advocación por lo que siendo del agrado de Vuestra Eminencia se podrá conzeder la aprovación que solicitan. Así lo siento salvo, et çétera.

Alcalá, y octubre 2 de 1765.

Excelentísimo Señor.

Doctor Don Alphonso Merino y Torres. 


\section{DOCUMENTO № 4}

1765, octubre, 9. Toledo.

Notas de escribano para la aprobación de las constituciones de la Esclavitud del Santísimo Cristo del Calvario de la villa de Mondéjar.

Archivo Diocesano de Toledo. Guadalajara 2. Expediente 12. Papel. 1 hoja. $200 \times 250 \mathrm{~mm}$. Buena conservación.

Toledo, y Octubre 9 de 1765.

Señores Carrasco, Sánchez e Hidalgo.

Se aprueban en la forma ordinaria. Rúbrica. 
DOCUMENTO № 5

1765, septiembre, 12. Mondéjar.

Poder otorgado a Cayetano Rodríguez Bermejo por Julián Arévalo y Zuazo, cura párroco de Mondéjar y todos los demás fundadores de la Esclavitud del Santísimo Cristo del Calvario de Mondéjar, para que les represente en la presentación de las mismas ante el arzobispado de Toledo.

Archivo Diocesano de Toledo. Guadalajara 2. Expediente 12. Papel. 3 hoja. $200 \times 250 \mathrm{~mm}$. Buena conservación.

In Nomine Domini Amen. Notorio sea a los que el presente poder vieren como ante mi el presente notario apostólico, vezino de esta villa de Mondejar y de los testigos infraescriptos, personalmente constituidos los señores don Julián de Arébalo y Zuazo, arzipreste y cura propio de la iglesia parroquial de Santa María Magdalena de esta villa, don Eugenio López Soldado, beneficiado en ella, don Julián Saabedra, don Féliz López Soldado, don Gerónimo Ramírez de Arellano, don Antonio Gutiérrez del Pozo, don Fernando Apolinar Urbano, don Nicolás Escudero, don Antonio Vicente de la Plaza, don Antonio Moreno, prior de ella, don Bernardo Sánchez Céspedes, clérigo de primera, en dicha villa, Juan Manuel Eusebio, alcalde hordinario por el estado noble en depósito, y Alfonso Ocaña por el principal, don Manuel Ramírez de Arellano, regidor por el dicho estado noble en deposito, Nicolás de Torres y Gabriel Ramiro, regidores por el principal, y Juan Saabedra y Guzmán, principal síndico por el referido estado noble depósito, todos dichos señores de esta dicha villa don Francisco Gutiérrez de Vegas, teniente administrador por su Magestad, Dios le guie, de las rentas y efectos del Excelentísimo Señor Marqués de Mondéjar, conde de Tendilla, et çétera, don Luis López Soldado, don Dionisio Gutiérrez del Pozo, don loseph Caio López Soldado, don Eugenio López Soldado, don Juan López Soldado, don Joseph López Soldado y Salcedo, don Pedro Alcántara López Soldado, vezinos y personas de esta expresada villa admitidas por el noble estado de hijosdalgo y como vezinos capitulares del estado general, Francisco Saavedra y Guzmán, Francisco de la Plaza, Nicolás Camacho, Juan Moreno, Francisco Jiménez Veltrán, Joseph Moreno, Alonso Maroto, Bernardo Aybar, Dionisio Camacho, Francisco Ribera, Manuel Moreno, Vicente de Torres, Cayetano de Torres, Vizente Alfonso Domínguez, Juan Francisco Polo Gutiérrez, escrivano del Rey Nuestro Señor, don Francisco Castellanos; $y$ otros vezinos por el estado general que son: Nicolás Ferrández, Antonio García Martínez, Juan Lucas García Martínez, Sebastián de Rueda, Melchor Martínez, Gabriel Ballesteros, Francisco 
Segovia de Phelipe, Phelipe Segovia, Francisco Segovia de Juan, Antonio Quintana, Juan Diéguez, Juan de Dios de Legazpi, Francisco Jiménez Alcalde, Manuel de Guevara, Alonso Segovia de Phelipe, Francisco Ximénez de Varrera, Bartholomé Ferrández, Andrés Ferrández, Alfonso López Ontova, Bernardo Pérez, y Manuel de Segovia de Phelipe; y dixeron que respecto de tener formadas ciertas constituciones y ordenanzas para extablecer a onrra y gloria del Santísimo Christo de el 15 Calvario que se venera en su santuario extramuros de esta villa y en su virtud, cumplir y executar los capítulos que en dichas hordenanzas se contienen y estando entendidos del derecho que en este caso nos compete, otorgamos en la mejor vía y forma que haia lugar que damos todo nuestro poder cumplido bastante como en derecho se requiere para valer a don Cayetano Rodríguez Bermexo, procurador en el Consejo del excelentísimo señor Cardenal Arzobispo de la ciudad de Toledo, en especial para que en nuestro nombre y representando nuestras propias personas pueda parezer y parezca ante su eminencia, señores de su consejo y otros juezes eclesiásticos que deban conocer, y demás que convenga y sea necesario, y presente las dichas ordenanzas echas y firmadas por nosotros mismos para que se formalize una congregación y esclavitud dedicada al Santísimo Cristo de el Calvario, y pida se admitan, bean y aprueben para su perpetuidad, pidiendo y suplicando que en conformidad de tan piadosa Hermandad y que todo va dirigido al maior culto del señor y bien y utilidad del Señor y bien y utilidad de los hermanos que pretenden la aprobación de esta hermandad tenga efecto la pretensión piadosa para que siendo servido su eminencia y señores de su Consejo por buenas, formadas y arregladas dichas constituciones se despache $/ 6$ el título o testimonio que hacredite estar aprovadas y en su consecuenzia seguir el orden de ellas en la forma que tenemos establezida dicha congregación o Hermandad que desde luego para cuanto fuere necesario le damos al expresado don Cayetano Rodríguez, nuestro poder abiente las facultades amplias y cunplidas sin limitación de cosa alguna para que forme y presente pedimientos y memoriales, súplicas, haga presentación de cualquier testimonios, certificaciones, probanzas, y otros documentos que convengan a esta pretensión solizite se hagan informes y las demás diligencias convenientes hasta que consiga tan justa pretensión que el poder que se requiere para lo susodicho, ese mismo le damos y otrogamos en todas sus inzidencias y dependenzias, anexidades y conexidades, libre, franca y general administrazión y con cláusula de que le pueda substituir en quien le pareziere rebocar los substitutos y nombrar otros de nuevo que a todos y a cada uno debamos en forma.

En cuio testimonio así lo otorgamos en esta villa de Mondéjar en /7 doze días del mes de septiembre año de mill setezientos sesenta y 
cinco. Siendo testigos Andrés de Buruaga, Julián López Ontova y Ramón Domínguez, vezinos de esta villa, y los señores otorgantes a quienes yo el notario doy fe que conozco, firmaron los que supieron y por los que no un testigo a su ruego,de todo lo qual yo el notario doy fee.

Don Julián Arévalo y Zuazo. Don Eugenio López Soldado. Don Nicolás Escudero. Don Julián Saavedra y Guzmán. Don Gerónimo Ramírez. Don Antonio Rivera. Don Antonio Gutiérrez del Pozo. Don Félix López Soldado. Don Hernando Apolinar y Urbano. Don Antonio Moreno. Don Antonio Vicente de la Plaza. Don Bernardo Sánchez Céspedes. Juan Manuel Eusebio. Don Manuel Ramírez de Arellano. Nicolás de Torres. Juan Saavedra y Guzmán. Eugenio López Soldado. Don Pedro Alcántara López Soldado. Don Luis López Soldado. Don Juan López Soldado. Don Francisco Ximénez. Don Dionisio Gutiérrez del Pozo. Nicolás Camacho. Bernardo Aybar. Dionisio Camacho. /8 Francisco de la Plaza. Alonso Maroto. Francisco Segovia. Melchor Martínez. Juan Dieguez. Antonio Saavedra. Esteván Fernández Moreno. Antonio Gutiérrez de Vegas. Lucas García. Andrés Fernández. Sebastián de Rueda. Juan Fernández. Bartolomé Hernández. Francisco Ximénez Alcalde. Eugenio Guzmán. Juan Francisco Polo. Juan de Dios de Legazpi. Francisco Urbano. Agustín López Soldado.

Testigo por los que no saben firmar: Ramón Domínguez.

Ante mí, Vicente Alfonso Domínguez, notario. (Rúbrica) (9)

Yo el dicho Vicente Alphonso Domínguez, Notario Apostólico y vezino de esta villa de Mondéjar, presente fuy a todo lo que dicho es, y en feé de ello lo signé y firmé, día de su otorgamiento.

En testimonio de verdad. (Signo).

Vicente Alphonso Domínguez. (Rúbrica). 
1765, julio, 25. Mondéjar.

Constituciones de la Esclavitud del santísimo Cristo del Calvario de Mondéjar.

Archivo Diocesano de Toledo. Guadalajara 2. Expediente 12. Papel. 20 hojas. $200 \times 250 \mathrm{~mm}$. Buena conservación.

Esclavitud.

Deseando promover el culto que en esta villa de Mondéjar se tributa al Santísimo Christo, venerado con el glorioso nombre de el Calvario en la Hermita del Santo Sepulcro de la advocación también de San Sebastián Extramuros de esta población, con el fin de perpetuar los obsequios que de unos años a esta parte se han rendido a su Magestad y arraigar en sus corazones de todos la debozión con el señor cruzificado en que se interesan las maiores cualidades y como en feudo y tributo de agradecimiento a sus favores, juntos el día veynte y cinco de julio de este presente año de mill setecientos sesenta y cinco, en la sacristia de la Parroquial de Santa María Magdalena de esta villa, con el cura Arcipreste, eclesiásticos, alcaldes, regidores y demás personas de amvos estados que acaso formaremos de común acuerdo y unida en una nuestras voluntades, tratamos fundar y establecer con las pruebas necesarias lizencias una esclavitud a honrra y gloria del señor cruzificado en el calvario con este nombre, de cuio cargo sea la celebridad de sus funziones y demás que aquí se expresare.

Las circunstancias de tan calamitosos /10 tiempos como hemos experimentado que podían retardar el cumplimento de nuestras ansias, son las que poderosamente nos estimulan y eficazmente impellen a la execución de este piadoso designio, persuadiéndonos a que ninguna ocasión más oportuna para acalorar las tibiezas y enzender fervorosamente los corazones en tan religioso intento que las de las tribulaciones con que nos ha havisado el Señor.

Quando os biereis afligidos, nos dize su Magestad por David, volberos a $\mathrm{mi}$, imbocar mi nombre, onrrarme y glorificarme que yo os consolaré en vuestros aogos. Nos hemos hallado consternados en la aridez de los campos y aún nos vemos amenazados con la merma, penuria, acongojados con la obstinazión de las nubes, desmaiados con las hambres y esterilidades y rodeados de otros muchos males, réditos que justamente pagamos del zenso de nuestras culpas, luego ahora es el tiempo en que, siguiendo la voz de el Real proteta, debemos en espezialidad con- 
sagrarnos a ofrecer alabanzas al Señor ahora que hallamos tribulaciones y dolores debemos ofrecernos a engrandezer, ensalzar y glorificar su santo nombre. Ahora es la ocasión de que tratemos a plazer con liberales cortejos sus justísimos enojos motivados según por sus profetas nos avisa del descuido de su culto e ingrata conrrespondenzia a los divinos favores.

Sembrásteis mucho, nos dize Dios por Ageo, y cogísteis poco, porque en pena de estar tan dilatados los senos de vuestro corazón para desperdiziar prodigamente en lo que me ofende y ultraja, los vienes que liberan os franqueo quando es tan estrecha la capazidad de vuestro spritu para emplearlos en lo que se de en onrra y gloria mía, eché yo candados al cielo para que negando a la tierra su rozío no correspondiere con frutos sacrificar al dolo de vuestras pasiones los haberes que os dispenso para que con ellos me sirváis, y en castigo dispongo que se sequen vuestros campos, que se thalen vuestras viñas y que no se vaje mi vendizión sobre vuestras tierras, repite por Oseas el Señor.

Estas calamidades con que amenazó Dios a su pueblo no son y han sido las mismas que hemos temido y lamentado. Nosotros temamos pues que experimentamos el mismo azote que aquel ingrato /12 pueblo, temamos juntamente ser reos de igual delito y conoziendo el infausto origen de estas miserias pongamos en el señor los ojos como sus esclavos, piadosamente confiados con David de que derramará sobre nosotros sus misericordias influencias.

Seguro apoio de nuestra cathólica esperanza tenemos en el estático profeta, consagrada acaso humildes como obsequiosos agasajos, dize que vió en el cielo una esclavitud onrrosa compuesta de veinticuatro ancianos, que postrados ante un herrmoso cordero, rendían a sus plantas las coronas y le ensalzaban con cánticos. Quando estaba asistido de estos esclabos llamase cordero el que se descubrió en al trono, siendo así que en otra parte se nos dize que era león, y es que aquella congregación de esclavos con sus festejos y gratas aclamaciones como por cierto modo superior y divino de encanto, le transformaron y trocaron la ferocidad en mansedumbre de cordero, emvargando sus rigores y suspendiendo sus iras y así mientras duraron los obsequios se manifestó $/ 13$ el león con semblante apacible de cordero pero luego que dieron fin al eco de unas trompetas llovieron sobre la tierra destrozos.

Esta representación y expreso geroblífico de las circunstancias de nuestro acuerdo en aquel cordero estubo simbolizado el redentor del mundo cruzificado en el calbario a donde su divinidad viva sustentó su humanidad difunta, en aquel león misterioso se significó también Christo en el Calbario, león generoso de Judea que luchando con el príncipe de las tinieblas le desposeió de su tirano imperio. En aquellos venerables per- 
sonajes y sus adoraziones está entendida nuestra comunidad de debotos y agradecidos pechos dedicados al culto, venerazión y festejo del cordero Christo cruzificado en el Calvario. Con que si aquellos esclavos consiguieron la dicha de mudar el riguroso zeño de un león en venigno aspecto de cordero, los que a su imitazión se empleasen en aplausos y obsequios del cruzificado dueño del calvario, podrán con fundamento esperar que, aunque como león irritado pretenda tomar venganza de las culpas, mitigará sus ardores y como piadoso cordero desatará venignidades mientras se bea /14 obligado con gratos rendimientos, ya para fomento de nuestra devozión nos lo viene acreditado la experiencia, pues hemos visto adelantados sus favores a nuestros reconozimientos, imploramos en la nezesidad que hemos padezido el auxilio de el Calvario solizitando sus misericordias con públicas rogatibas y como al Señor no se le ocultan los más escondidos secretos del corazón humano, azeptando los vivos deseos que pulsaban nuestros animos de establecer a onrra suia esta esclavitud, nos socorrió con copioso riego. Motivo que nos empeña tanto más, quanto nos consta su complazencia en que se gratifiquen sus piedades y su enojo en que se sepulten al olvido.

Por tanto estando ziertos de que todos los que reberenzian, adoran, sirben y festejan al señor son coronados y premiados con sus grazias, prometiéndonos que serán glorificados los que le glorifiquen en el nombre de la Santísima Trinidad, Padre, Hijo y Espíritu Santo, tres personas distintas, un solo Dios verdadero, misterio que firmemente creemos y confesamos con todos los que nos enseña nuestra Santa Madre Iglesia, Católica, Apostólica y Romana, valiéndonos de la soberana protección de María santísima, madre de Dios y Señora Nuestra en el Inmaculado misterio de su concepción en grazia de el patrozinio de la enamorada de Christo, Gloriosa Santa /15 María Magdalena, nuestra titular, y de el fabor de el esclarecido martir San Sebastián, queremos fundar y establecer, y fundamos y establecemos a onrra y gloria de Christo cruzificado en el Calvario esta esclavitud con las reglas y constituziones siguientes:

1․ Por quanto todos somos obligados al Señor que sin exzepción de persorias se ofrezió en sacrificio a su eterno padre y cruzificado en el Calvario derramó su preziosísima sangre por el linaje humano y enderezándose la presente esclavitud ha protextar nuestro debido reconozimiento a extender el culto del señor, y unidos en charidad, cuidarnos mutuamente unos a otros, nos parece conveniente que el número de esclabos no sea zeñido y limitado sino que se admitan a los debotos de uno y otro sexo, así vezinos de nuestra villa como forasteros que quisieren alistarse concurriendo en ellos las siguientes condiziones. 
$2^{a}$. Los que hubieren de admitirse por esclavos han de ser descendientes de christianos viejos limpios de toda mancha y traza de moros, judios y penitenziados por el Santo Oficio, católicos, apostólicos, romanos, no notados de sospechosos en la fee, ni de imfames, ni de blasfemos, maldizientes, escandalosos y públicos pecadores que 116 desde luego queremos que estos queden excluidos, sino de buena vida y costumbres, virtuosos, modestos y de edificazión.

$3^{\mathrm{a}}$. En conformidad de lo ya hordenado, el que pretendiese alistarse por esclavo se presentará ante el socio maior que lo será siempre el arzipreste, cura que es o fuese de esta parroquial, y en su ausencia su theniente, para que antes que se haga propuesta a la esclavitud de su pretensión, pueda informarse en secreto (como el pretendiente no sea sacerdote a quienes suponemos por su estado dignos $y$ veneméritos $)^{45}$ de su calidad, prendas y costumbres y si por alguna causa le hallase indigno, pueda con paternal afecto corregirle que eviten las discordias que de no ser admitido en lo público podrían originarse y el sonrojo y confusión que padezería el pretendiente en su repulsa siendo notoria, como también el que por precaber estos inconvenientes sean admitidos los que lo desmerezcan.

4․ Practicadas todas estas diligencias por dicho señor abad de quien se confia obre ageno de toda pasión y siniestro afecto, enterada de la dignidad de el /17 pretendiente y enmendado en lo que justamente fuere corregido con acuerdo de los consiliarios, se le sentará por medio de el secretario en el libro que para este fín tendrá la esclavitud y admitido que sea se le leeran las ordenanzas, para que con su notizia trate de cumplirlas y observarlas y en la primera junta siguiente a su admisión se hará presente a los esclavos para que le reconozcan por individuo de la esclavitud.

$5^{a}$. Será obligación de esta esclavitud costear anualmente la funzión que se ha de hacer al Señor en esta parroquial el día catorze de septiembre, festividad de la exaltación de la Santa Cruz, traiendo a su Magestad el día antes desde su hermita en solemne prozesión a esta iglesia con asistencia de todos los esclavos, que llevarán luzes enzendidas y el día de la fiesta en que habrá misa, sermón y por la tarde vísperas, se conduzirá con igual magestad a su hermita. Por ahora en cuanto que se halle la esclavitud con fondos para que quede en nobena, y si el tiempo no lo permitiere se hará to referido el domingo siguiente.

45. En el original entre paréntesis. N. del A. 
6a . El día de la función ordenamos que por el señor abad o a quien este lo encargare se zelebré por la salud y /18 aumento de esta esclavitud otra misa rezada a la ora que se publicará el día antes para que comulguen en ella todos los esclavos, que serán obligados ha confesar dicho día catorze o su víspera, con cuia diligencia visitando el santuario en que se venera el Santísimo Christo y rezando en él por la exaltación de la Santa Fe Cathólica, extirpación de las erejías y victoria contra los infieles, podrán ganar la indulgencia plenaria que por tiempo de siete años tiene conzedida a todos los fieles de uno y otro sexo Nuestro Santísimo Padre Clemente Treze, y habiendo su santidad dispensado igualmente, y en la forma dicha, la misma grazia para el día diez y seis de agosto y el día jueves de la Zena de Nuestro Señor Jesuchristo, exhortamos y encargamos a todos la misma diligenzia.

$7^{a}$. Al día siguiente de la funzión se harán honrras generales por los difuntos de esta esclavitud con misas con diáconos y vigilias pagando lo que se hacostumbra de derechos, y todos los esclavos que no constare hallarse ausentes, enfermos o legitimamente ocupados de lo que darán abiso, asistirán el día de la fiesta a las onrras vajo la pena de un libra de zera que se les exigirá irremisiblemente como no prueben su ausencia de /19 esta villa $u$ otro legítimo impedimento.

8a. Para soportar el gasto de la función principal de esta esclavitud, misa rezada de el dia y onrras, se nombrarán ocho sujetos de la misma esclavitud y estos habrán de ser los que lo costehen por partes iguales a excepción de el que entre ellos debe llevar la voz de hermano maior que éste, como avajo se dirá, ha de concurrir con maior limosna.

$9^{a}$ Porque los gastos superfluos que ha introducido la banidad es el más fijo antecedente de que se sigue la funesta consecuenzia de deteriorarse las congregaciones, no siendo como son agradables al Señor, antes muchas vezes injuriosas, resultando grabes ofensas a su Magestad, ordenamos conforme a lo que tiene estrechamente mandado el excelentísimo señor cardenal Córdova, nuestro dignísimo prelado, que por ningún título ahora ni en tiempo alguno haia de haver refrescos, comidas y otras superficialidades semejantes, lo que queremos que se cunpla y guarde por nosotros y los que nos subzedan inviolablemente, que si alguno lo contrario hiziere tenga entendido que se le expelerá y borrará de la esclavitud /20

10a. Atendiendo a la subsistencia y perpetuidad de esta esclavitud, para lo qual conduze no gravar demasiadamente a sus individuos, determinamos, hordenamos y tasamos lo que cada uno ha de gas- 
tar en el año de su maiordomía, que será cinquenta reales de vellón, que multiplicados por siete que han de ser los maiordomos, importa todo trescientos y cinquenta reales, cuia cantidad es suficiente para cumplir los referidos gastos, que se han reduzido y regulado en esta forma:

Por los derechos parroquiales de señores cura y beneficiados de la misa cantada, vísperas y pozesiones, treynta y seis reales, según estilo de otras funziones..

Para sacristanes y campaneros, por lo dicho, quarenta reales de limosna.

Por la misa rezada, quatro reales.

De las honrras, por todos derechos, treynta y dos reales del situado.

A esta Iglesia, por las dos funziones, onze reales.

De una arrova de zera para el altar, dozientos y seis reales.

Que todo compone, trezientos veynte y nueve reales, y los veyntiuno restantes para la conduzión de la zera, exceso que pueda haver en su prezio y hazer el altar.

Y por lo respectivo a pólvora, no se les obligue a los maiordomos a este gasto y espezialmente pro /21 hibimos que durante la prozesión ni inmediatamente antes ni inmediatamente después se disparen fuegos, según como tiene nuebamente mandado nuestro excelentísimo prelado.

$11^{a}$. Entre los ocho esclavos que como maiordomos han de costear lo referido, el uno de ellos será quien llebe la voz de hermano maior cuio gasto, como el de los siete nominados maiordomos igualmente que el de ellos, queremos tasar y tasamos, hordenando como hordenamos que en el año que le toque ser hermano maior no tenga otra pensión ni contribuia más que con sesenta y çinco reales del sermón que es la limosna que se señala, siendo de su cargo llevar al prior a su casa hacompañándole al púlpito con los demás maiordomos, y le dejamos libre y puramente electivo del hermano maior el derecho de elegir orador, atento a que quando esto depende del consentimiento de muchos, no pocas vezes nazen en los ánimos inquietudes y deshuniones que perturvan el fin que el mismo nombre de confraternidad está indicando. $Y$ para obrarlas en un tooio dará parte al señor abad del predicador que destine y procurará que sea sujeto idóneo, en /22 cargando siempre a qualquiera que fuese que omitiendo impertinentes circunstancias, explique un punto de doctrina christiana en el exhordio conforme a lo que repetidas vezes está mandado. 
$12^{a}$ Haziéndonos cargo de que en la forma enunciada no será para los esclavos gravoso servir la maiordomía y previniendo, el que con el tiempo pueda llegar el caso de que alguno de los nomvrados que se halle con medios suficientes pretenda sobresalir en el luzimiento de su funzión de que se sigue que otros con una emulación, hija, más de la banidad y amor propio que del zelo santo del culto del señor, ha su imitazión con perjuicio de lo temporal y sin aprobechamiento espiritual, exzedan asimismo en los gastos:

Ordonenamos (sic) que el hermano maior pueda reservar en sí los setenta y cinco reales del sermón que es de su cargo pagar, pero los demás maiordomos contribuirá cada uno con la cantidad que le cabe en el día de la imbenzión de la Santa Cruz, que habrá junta general que entregará de ello al thesorero para /23 que éste en el tiempo oportuno dé a los dos consiliarios más antiguos, que son los que han de disponer la funzión, lo nezesario para ella. Evitándose asimismo por este medio otras disensiones que entre los nombrados maiordomos fazilmente podrían ocurrir.

$13^{\mathrm{a}}$. La eleczión de hermano maior y mayordomos, para impedir que se haga con siniestras intenziones y precaber otros ynconvenientes, ordenamos que se haga alternando en cada un año, quatro de maior hedad y quatro de menor, empezando a servir dichos cargos los quatros más anzianos y los quatro más jóbenes, siguiendo con este mismo orden en lo subzesivo, dándole la graduazión de hermano maior al más anziano, como no sea que alguno de los menores sea sazerdote, que en este caso lo preferimos para el dicho cargo por la dignidad de su estado, y haviendo dos sazerdotes, será el hermano maior el más antiguo de los dos.

$14^{\mathrm{a}}$ Los quatro de menor hedad, ordenamos que puedan ser aún los párvulos y todos los que esten vajo la patria potestad que haian sido admitidos 124 con el consentimiento de sus padres y tutores, por lo que hasta que conste de la voluntad de estos no se les alistará por esclavos, pero prezedida su lizenzia se les admita y quando les toque el turno de la maiordomía se les obligue a la paga, respecto de que notiziosos de esta constituzión son árbitros para mandar que se les alisten por esclavos o no, de una vez que consintieron en su admisión es visto haverse sujetado en su nombre a esta carga.

15a . En este turno para el servizio de la maiordomía no entrarán las mujeres, como tampoco en las juntas ni en cosa impropia de su sexo, pero si voluntariamente quisieren y lo pidieren será admitida la que lo solizite constando el permiso de su maricio; y en este caso solizitándolo dos, se dejará de proponer para la maiordomía 
a un anziano y a un joben y si fuese una sola se dejará de nombrar a uno de los jóbenes, y así respectivamente si se ofrezieren tres, o cinco, o siete, de cuio número no podrán pasar, porque siempre ha de aver uno en clase de hermano maior que será según se a dicho el más anziano. Pero el señor abad podrá nombrar a alguna de las esclavas por /25 camarera.

16 . Si haviendo ya servido todos los esclavos los empleos dichos, volbiese por turno a repetirse esta carga hallándose esta esclavitud, como suponemos, con fondos para costear las funciones y sufragios con el depósito que de el rédito anual de los demás esclavos se rinda, según su número se hará la proposición de individuos según por su hedad les tocase, pero en este caso serán libres para azeptar y escusarse de su empleo de manera que sea visto que el que lo sirviere entonzes lo sirbe sólo por devozión y no por obligazión, porque se les ha de admitir la escusa que se ha de hazer la funzión con los caudales que paren en poder del thesorero en el todo o en la parte, de manera que de si los ocho que se nombran azeptase uno, dos o más, lo que faltó se suplirá del caudal, y no azeptando ninguno, el consiliario más antiguo tendrá la preheminenzia de hermano maior en el asiento y llevar el estandarte en la prozesión, en el caso de que el thesorero de esta esclavitud se excusase, que es el primero a quien se le ha de nombrar en dichas circunstancias por hermano maior y el que con acuerdo del señor abad encargará el sermón azeptando dicho empleo. Y sino el que le azeptase /26 havonándole del caudal así la limosna para el orador como el gasto que con la devida moderazión causare si quisiere contarlo. $Y$ si subzediere que esta esclavitud se hallase al dicho tiempo sin caudal para costear la funzión, o por haverse impuesto el que havía a veneficio de ella o por haverse consumido en sufragios con el demasiado número de esclavos que haian fallezido, exhortamos, encargamos y confiamos que no alcanzando la anual contribuzión de aquel año para costear la funzión, se esfuerzen todos y cada uno a proporzión de sus facultades para que no se suspenda ni zesen los sufragios mediante a que en igual caso que de nuevo en lo futuro ocurriere a exemplo suio y en utilidad propia, lo practicarán los subzesores si la próxima vez que acaeziere lo hizieren los que entonces vivan, cuio punto se exsaminará y tratará en Junta general.

17 . Como en la asignación referida de maiordomo en el número de ocho es solamente nuestra intenzión no imponer obligaziones superiores a las comunes convenienzias de los esclabos, sino ligeras y moderadas, declaramos que no obstante lo prevenido en la /27 constituzión octava pueden servir la maiordomia y costear la fun- 
zión los individuos de esta esclavitud en el número de uno, de dos, de tres y de cuatro quando ellos para deshaogo de su devozión, impazientes de esperar el turno de sus hedades, voluntariamente lo pidieren, en cuio caso permitimos que se invierta la alternativa señalada y ordenamos que se les admita su propuesta con preferenzia de el que la pida sólo al que la pida con otro, de éste al que la pida con dos y de éste al que la pida acompañado de otros tres, pero con la prezisa condizión de que lo hagan presente la vispera de la fiesta antes de que se prozeda al nombramiento por el orden regular de las hedades, porque azeptado el nombramiento en el número de ocho, de dos, de tres o de quatro no habrá lugar a su pretensión, y si antes que ocurriendo que el referido tiempo pidiesen muchos serbir dichos cargos, será hatendido el menor número y es número igual el primero que se declarase, y así a unos como a otros no se les obligará quando les toque por su turno pues es visto haver cunplido, pero /28 se les admitiría si ellos quiseren de nuebo.

18․ Si alguno de fuera de esta esclavitud por promesa, devozión u otra causa quisiere costear y hacer la función luego que de parte no se le impida, antes si estando ausente se le escrivirán a nombre de la esclavitud las grazias por el secretario y costeando él sólo toda la funzión, se le hará presente que queda admitido por esclavo aunque es lo subzesivo no concurra con la limosna que anualmente ha de dar cada un esclavo, y así que gozará los sufragios y partizipará de las indulgenzias que se conzedieren a esta esclavitud, preveniéndoles encargue a sus hermanos o albazeas den notizia segura de su fallezimiento al señor abad para que se dispongan y manden dezir las misas que avajo se señalarán. Y por que se puede subzeder que se tenga la notizia después de echo el nonvramiento de maiordomos a qualesquiera que lo fuesen, como /29 ya no tengan entregada al thesorero en el día señalado su respectiva limosna, mandamos tengan a bien no exerzer en aquel año sus empleos y contribuir como esclavos particulares y les aseguramos su uso en el año siguiente conviniendo así al bien de esta esclavitud, pero si huvieren puesto en poder del thesorero la limosna que les toca queda a su advitrio el zeder o no, vien que quisieramos no se fustrare el buen deseo del forastero pretendiente, a quien en el caso de no zeder se le escrivirá pretextando lo que se considere oportuno para no enturviar su debozión y darle gusto en el año siguiente y asistiendo en persona a la funzión se le guardará el onor de hermano maior. 
19. Respecto a que son admitidos los forasteros en esta esclavitud y que no les es tan fazil la contribuzión anual como a los vezinos de esta villa ni tampoco el servir dicha maiordomía, ordenamos que puedan indultarse de una y otra carga, dando por una vez dozientos reales de vellón con cuia cantidad queda $/ 30$ rán libres de la anual pensión y servizio de maiordomía y conoziendo ser esta disposizión favorable hazia todos qualquiera esclavo vezino de esta villa quedará también exonerado en la misma forma dando de una vez dicha cantidad. Y a unos y a otros se les harán los sufragios que para cada uno de los que haian sido maiordomos o hermano maior se señalasen y con más razón al que por si solo costease la funzión, pero en el caso de que el forastero no quiera o no pueda valerse de este yndulto dejará sujeto vezino de esta villa por cuio medio entregara la limosna anual y se obligará al cargo de mairodomo o hermano maior quando le tocare, conviniendo asi para la seguridad de la funzión y en otra forma no serán admitidos mientras la esclavitud no tengo vezino de este pueblo a quien con oportunidad pueda acudir en caso nezesario.

$20^{\mathrm{a}}$. Todos los esclavos en los años que no les toque servir la maiordomía han de concurrir con la /31 limosna de quatro reales de vellón en cada un año, que se han de entregar en la junta que se zelebrará el día de la Invenzión de la Santa Cruz y depositar en poder del thesorero. Pero por si algunos en aquel preziso día se hallasen sin la dicha limosna, permitimos y prorrogamos el tiempo asta la víspera del día catorze y encargamos al thesorero que fuese que en qualquiera otro día del año antes de los referidos que acudiese a él algún esclabo con dicha limosna la reziba y anote en el libro que tendrá para su gobierno y formazión de las quentas que en cada año se le han de tomar.

$21^{2}$. Dirigiéndose la menzionada anual limosna de todos los esclabos al fin de tener fondo para disponer las misas que se han de zelebrar por los difuntos, luzes para los entierros, renuebo de las que sirban para la prozesión y además que parezca combeniente para perpetuar al señor el culto, aumentarle como también los sufragios por los esclavos, /32 ordenamos y entrechamente mandamos con arreglo a las constituciones sinodales de este arzobispado que en ningún aconiezimiento se destine parte alguna del caudal de esta esclavitud para corridas de toros o novillos, comedias, ni otros gastos profanos, prohibiendo igualmente según lo está en las citadas sinodales que el día de la funzión y como en honrra de la fiesta tengan los maiordomos ni otro esclabo alguno funzión de bayle, como en demostrazión de festejo siendo tan impropio zelebrar los misterios que su magestad consumió en el calvario a costa de tan- 
tas penas con semejantes abusos. Todo lo qual queremos que se guarde y cumpla ahora y en todo tiempo, vajo las penas contenidas en dichas sinodales y en caso de contumazia pena de expulsión dela esclavitud.

22a ${ }^{a}$. Siendo justo que cada uno participe de las utilidades de esta esclavitud a proporción de la maior o menor debozión que en beneficio de ellas hubiese manifestado, disponemos por ahora reservando para /33 tiempo en que se halle con más fondos, maior aumento el número determinado de misas con que se ha de socorrer a los difuntos esclabos y esclabas en la forma siguiente:

Cada uno de los que fallezcan antes de cumplir el cargo de hermano maior o maiordomo, tendrá a veneficio de su ánima, diez misas rezadas que con la limosna hordinaria se han de zelebrar en esta parroquial.

Los que fallezcan después de haver servido dichos cargos o de haverlos azeptado suponiendo que an de estar obligados ha cumplirlos por si sus herederos y albazeas tendrán en veneficio de su ánima veynte misas como también las esclavas que voluntariamente los sirvieren hacompañándose con quienes por el turno de las hedades correspondan entre los hombres; y asimismo gozarán dichos sufragios los que se valieren del indulto conzedido en la constituzión diez y nueve. Los que voluntariamente fuera del turno sirviesen dichos cargos en el número de quatro, tendrá cada uno en falleziendo, treynta misas, si en el número de tres, cada /34 uno treynta y cinco; si en el número de dos, quarenta, y el que costease por si solo la funzión, sea vezino o forastero no esclavo, tendrá en falleziendo cinquenta misas y aquellos que haviendo ya servido una vez dichos cargos le sirvieren tocándoles segunda vez el turno, tendrán sobre las veinte misas señaladas diez misas más y a este modo con la proporzión respectiva ya insinuada se duplicarán los sufragios según cada uno hubiese repetido los exmeros de su debozión.

23‥ Para ro dilatar los señalados sufragios a todos y a cada uno de los esclavos según y como están señalados ordenamos:

Que luego que conste del fallezimiento de qualquiera de ellos se libre por el señor abad y por medio del secretario contra el thesorero la cantidad nezesaria para los sufragios que al difunto, según el arreglo echo, correspondan y se repartirán prontamente con toda equidad. 
24a. Asimismo atendiendo a la maior contribuzión /35 del hermano maior y maiordomos ordenamos:

Que aquel sea distinguido con llevar el estandarte del Santísimo Cristo en la prozesión y no pudiendo al esclabo que delegare; y sentarse en lugar preferente junto al señor abad en todas las juntas que se hizieren. Y para que el día de la funzión concurra la esclavitud en forma de comunidad se pondrán los bancos siguientes:

A los bancos de los señores alcaldes que quedarán en los propios sitios que ocupan ahora con todos los demás señores del ayuntamiento en cuio arvitrio queda permanecer en su acostumbrado lugar aún quando alguno sea hermano maior o maiordomo o ponerse en los dos bancos que a estilo de otras funziones se pondrán por vajo de las gradas del presbiterio, uno detrás de otro, en el primero los anzianos y en el segundo los jóbenes maiordomos, pero los demás individuos se sentarán con llaneza sin señalamiento alguno, echos cargos de que la magestad de el redemptor ha cuio obsequio se consagra esta esclavitud se anonadó por nosotros y encargó $/ 36$ repetidas vezes que el maior se preziase de ser menor y en especial quando dezidió la controversia que sobre las maiorías se subszitó entre los diszípulos. Bien entendido que no por esto queremos impedir que se use de la urvanidad y política tan devidas a las prendas y carácter de algunas personas, antes la recomendamos en gran manera que deseamos que se guarde pues sólo en el intento de prevenir a los humildes que no se ensalzen y a los elevados advertirles que se humillen. Todo lo qual queremos que se observe así en las juntas como en el día de la fiesta en el qual los señores eclesiásticos podrán permanecer en su coro en qualquier acaso. $Y$ para que los maiordomos sean en la prozesión distinguidos llevarán las barbas del estandarte dos de ellos y irán alumbrando los restantes inmediatos a la santísima imagén y clero. Por ahora en el ínterin se pueden costear unos zetros con los que a su tiempo irán en medio de la prozesión con la antelación que a sus $/ 37$ hedades correspondan.

25a . Para el día catorze, que como se ha dicho, celebrará la esclavitud su fiesta prinzipal, en su víspera se nombrarán dos esclavos que pidan de la parte de afuera de la iglesia, según lo dispuesto nuevamente por Nuestro excelentísimo prelado, limosna para el Santísimo Christo y la que se recoja se entregará al thesorero, $Y$ si se dispusiere pedir lizenzia para exponer a su magestad se nombrarán tanvién por oras los esclabos que deberan velar. 
26a . El dia de la funzión por la tarde, antes de salir a la prozesión por el libro en que estarán alistados los esclabos con expresión de sus hedades, se hará la proposizión y nombramiento de hermano maior y maiordomos; y echo que sea, o bien en la forma permitida en la constituzión diez y siete; o bien por el turno regular se publicarán por el sacristán los nuevamente electos, saldrán a la prozesión llebando el hermano maior el estandarte y los demás mayordomos como está prevenido en la antezedente.

$27^{\text {a }}$. Todos y cada uno de los esclavos dispondrán a una vela de zeras de a libras para alumbrar en las dos prozesiones de esta esclavitud, en las dos $/ 38$ que se hazen con el Señor Sacramentado en sus festividades y quando se ponga en rogativas a nuestro soberano dueño del calbario, pero en otras fiestas y prozesiones no se les obligará a que saquen las velas, pero pidiéndolas para su determinazión se juntarán a lo menos, el señor abad, hermano maior, thesorero y consiliarios y no en otra forma.

$28^{\mathrm{a}}$. En la arca de la zera con los sobrantes de la de el altar se guardarán las velas de los esclabos que las dejaren y de todos los que fallezieren y se renovarán a costa de la esclavitud, mas no las de aquellos que las quisieren llebar a su casa que las mantendrán en pie a su costa. Y así mismo se reservarán en dicha arca quatro achas que del caudal de esta esclavitud se comprarán por ahora destinadas a que sirvan en las prozesiones que salgan fuera de la yglesia, con tal que mutuamente se correspondan a las nuestras, a lo menos con igual número con la zera de las imágenes a cuio obsequio se hazen como también para que acompañen al señor quando se diese por beático a algún esclavo y para que /39 luzcan en la yglesia mientras el ofizio de sepultura de qualquiera individuo. Pero si alguno de dentro o fuera de la esclavitud pidiere la asistenzia de esta con velas se le conzederán y hacompañarán al cuerpo con ellas enzendidas desde la casa a la yglesia y en ésta se pondrán junto al cadaver las quatro achas con tal que pague dos ducados si fuere esclabo y no lo siendo quatro ducados y sea visto que en uno y otro caso cumpla la esclavitud con la asistenzia de veynte esclabos con velas.

29․ Quando caiere enfermo alguno de los esclavos procurarán todos visitarle y a lo menos luego que se le dé el beático se nombrarán por el señor abad dos que a nombre de la esclavitud le visiten. Falleziendo todos los que no se hallaren ausentes o justamente impedidos asistirán, teniendo presente que Nuestro Cruzificado Dueño aunque fue rogado para ir a casa de aquel reiezuelo no condeszendió y fue a casa del pobre criado dejándonos exemplo para que más bien que con los pobres y humildes se omitan con 
los elevados los ofizios de piedad y caridad christiana. Pero se previene que para esta asistenzia $/ 40$ goze de sufragios y demás grazias de esta esclavitud habrán de ser actualmente esclavos, al tiempo que fallezcan habiendo cumplido en los años antezedentes con su contribuzión y cargos, bien entendido que en el caso de que alguno haia dejado de concurrir con su limosna por haver venido a pobreza solemne examinada y justificada ésta en la junta compuesta a lo menos de tres indibiduos, se le tendrá por esclabo, se asistirá a su entierro y se zelebrarán por él las misas que le correspondan, pues lejos de hazerse indigno de este venefizio por su escasa fortuna se haze acreedor tamvien a que mientras vivo se le atienda y socorra, lo que se tendrá presente para que en semejantes ocurrenzias haviendo fondos se libre alguna aiuda de costa.

$30^{a}$. Además de la junta del día catorze se hará también ocho días después en el primero festivo otra junta para nombrar un thesorero, quatro consiliarios, un secretario, y un mullidor, si los $/ 41$ antezedentes no quisieren proseguir o en esto no se convenga la esclavitud lo que se practicará en esta forma:

El thesorero propondrá dos, siempre abonados con el cargo de responsabilidad. Los consiliarios uno cada uno, empezando el más antiguo de ellos según su hedad o la dignidad de su estado y siguiendo con este orden. Los demás y el secretario otro y sentándose en un papel separado los nombres de los propuestos cada uno de los esclavos por el orden de sus asientos, llegará al señor abad que se pondrá separado y dará su voto en secreto quedando electo el que tenga maior número de votos. Pero se previene que en quanto al thesorero se ha de elegir sin salir de la propuesta de los dos, que saliendo de ella quedarán responsables a qualquiera quiebra que haga y no el thesorero nominador. Mas si los consiliarios o secretario que se propone no se juzgasen convenientes, sigilosamente podrá cada un esclavo en su voto repellerlos y dezir quien les parezca más util y si los demás acordasen la misma elección se estará a la pluralidad de sus votos, y en quanto al mullidor, contemplándole como esclavo /42 digo, como criado de la esclavitud, si cumpliere y quisiere proseguir quedará por mullidor y muriendo en actual servizio se le tendrá por tal esclabo para el goze de los surragios aunque no haia concurrido con la limosna de los quatro reales y estará exonerado de servir la maiordomía.

$31^{\text {a }}$. Echo el nombramiento de los referidos enpleos o continuando los antiguos darán quentas el thesorero y consiliarios de los gastos causados dentro de el año, del caudal que han rezivido y se habonarán las partidas que con libramiento del señor abad y dos 
consiliarios y hermano maior si hubieren entregado, dando asimismo quentas los dos consiliarios de lo que hubieren rezibido para el gasto de la funzión y el thesorero de los esclavos que haian sido moroso en contribuirle con la peseta anual y estendidas y firmadas en el libro. El alcanze que resultó a favor de la esclavitud se entregará al nuevo thesorero en el término de treynta días o quedará en su poder firmándolo él, si prosigue con los dichos abad y /43 consiliarios, como también el que de nuevo se eligiere. Y si saliere alcanzada la esclavitud y no quisisere proseguir el nuevo thesorero a nombre de ella y de sus rentas y efectos se obligará a continuazión de la azeptazión de su nombramiento a la paga, firmando igualmente dicho señor abad, hermano maior y consiliarios con el secretario ante quienes se han de tomar las quentas.

$32^{\mathrm{a}}$. Los dichos thesorero y consiliarios cuio ofizio será del uno rezivir, guardar y entregar los caudales de esta esclavitud pedidos en la forma dicha y de los otros, exponer su parezer en todo lo conveniente a esta esclavitud, disponer los dos más antiguos la funzión y todos quatro rejir la prozesión cuidando de su buen orden y de que las luzes vaian juntas, tendrán prezisa intervenzión en todas las juntas que para el buen rejimen fueren nezesarias y siempre que hubiese que imponer o emplear a veneficio de esta esclavitud firmando las escripturas que en su razón se hiziesen con el señor abad y hermano maior, si supiere firmar procurando siempre dichos consiliarios y thesorero la seguridad, tomando para ello $/ 44$ los informes nezesarios. $Y$ el secretario habrá de asistir tanvién prezisamente a todas las juntas y entender los acuerdos y deliberaziones. En el libro de esta esclabitud que havrá para la formazión de quentas y esrivirá también en otros separado los que se alistaren por esclavos y nombramientos de oficios.

33ª . La junta del día de la invenzión de la Santa Cruz se dirigirá a la recaudazión de la limosna, así de los maiordomos como de los esclabos. Tratar y conferir sobre los morosos en la paga y exaczión de las multas en que haian incurrido y todo lo que se judgase conduzente al bien de esta esclavitud guardando así en ésta, como en las dernás juntas que se zelebren, a que prezisamente han de concurrir con los dichos en la constituzión antezedente otros esclabos hasta componer en número de treze para que se esté y pase a lo que se determine, guardando en todo secreto y orden de dar cada uno su dictamen separadamente y no con tumulto y confusión $/ 45$

34a․ Así a la funzión como a las honrras, juntas y entierros y demás que se ha expresado ser del cargo de todos y cada uno de los esclabos, ordenamos que asistan todos los que no estuvieren au- 
sentes de esta villa ni hizieren constar legítimo impedimento que les excuse y cumplan y guarden todos y cada uno de los particulares que comprehenden estas constituziones, bajo la multa y pena de una libra de zera y demás contenidas en estas ordenanzas, para cuia exaczión vastará el abiso que se dé por el mullidor de esta esclavitud y si repetido tres vezes no correspondiere, el alcalde más antiguo que es, o fuere, le pueda compeller a la paga.

35․ Siempre que pareziese conveniente expeller algún individuo o por sedizioso o por inovediente o por incorregible u otro defecto que no /46 fuese público, prezederán primero tres correciones guardando en todo el orden de caridad según y como está prevenido en la constituzión terzera, pero si fuera su crimen público y notorio se le cerrará y tildará sin dicha cautela. $Y$ en uno y otro caso encargamos no se prozeda con ligereza y que antes de expeller a qualquiera se examinen las causas y motivos que hubiese dado con la maior madurez, reflecsión e intervenzión sinzera.

36 . Todos aquellos que no subscribieren a estas ordenanzas ni se alistaren por esclabos hasta el día catorze de septiembre de este presente año, han de pagar a su entrada onze reales de vellón y sufrir la carga de la maiordomía en el año de su entrada si entonzes les tocare por su hedad y estarán asimismo obligados ha confesar y comulgar el día de su entrada que para los presentes $/ 47$ fundadores será dicho día catorze y en esta forma y no en otra serán admitidos.

$37^{a}$. Si en algún tiempo o por variar las circunstancías o por otras causas fuese preziso quitar, inobar o añadir algo contrario en todo o en parte a estas constituziones o alguna de ellas, se harán tres juntas para más exacto conozimiento y lo que se hacordare en la última por consentimiento de dos partes de votos de las tres que concurran y fuese para servizio de Dios, Nuestro Señor, espiritual aprovechamiento de los esclabos, se estenderá en el libro y aprovado dicho acuerdo por el excelentísimo señor Arzobispo de Toledo, que es o fuere, tenga la misma fuerza que aquella o aquellas ordenanzas que por el dicho acuerdo se rebocaren como si haora se hubiesen extablezido, como en efecto se hubiera hecho a haver tenido presente el motivo que por entonzes ocurra bajo las quales reglas, ordenanzas y constituziones a que nos obligamos $/ 48$ y queremos se obliguen los que subzedan, fundamos como esclavitud a onrra y gloria del Santísimo Christo del Calbario y bien de nuestras almas y pedimos y suplicamos al Excelentísimo Señor Cardenal, Arzobispo de Toledo, se digne rezivirnos vajo de su vendizión y aprobar y confirmar esta esclavitud y sus constituziones que por nuestro apoderado serán presentadas para que de ahora y en lo subzesivo se cumplán, observen y guarden como deseamos. 
Y lo firmamos en Mondéjar, y jullio, veynte y cinco de mill y settezientos sesenta y cinco años.

Emendado: rendido, eco, el, pa, también, ocho, D. Valga.

D. Julián Arévalo y Zuazo. Don Eugenio López Soldado. D. Nicolás Escudero. D. Julián Saabedra y Guzmán. D. Gerónimo Ramírez. D. Félix López Soldado. D. Antonio Rivera. D. Antonio Gutiérrez. D. Fernando Apolinar y Urbano. D. Antonio Moreno .D. Antonio Vicente de la Plaza. D. Fernando Sánchez Céspedes (49). Juan Manuel Eusebio. D. Manuel Ramírez de Arellano. D. Eugenio López Soldado. D. Luis López Soldado. Antonio Gutiérrez Vegas. D. Joseph López Soldado. D. Nicolás de Torres. Francisco Ximénez. D. Dionisio Gutiérrez del Pozo. Agustín López Soldado. Juan Saavedra y Guzmán. Nicolás Camacho. Bernardo Aybar. D. Pedro Alcántara López Soldado. Francisco de la Plaza. Dr. D. Francisco Antonio Gutierrez. Alonso Maroto. Melchor Martínez. Dionisio Camacho. Fernando Gutiérrez. Francisco Segovia. Juan Diéguez de Vegas. Esteván Fernández Moreno. Andrés Fernández. Antonio Saabedra. Sebastián de Rueda. Juan Fernández. Bartolomé Hernández. Francisco Ximénez Alcalde. Lucas García. Eugenio Guzmán. Juan Francisco Polo. Juan de Dios de Legazpi. Francisco Urbano. ${ }^{46}$

46. Todos ellos con sus correspondientes firmas y rúbricas. 